I NTER NATIONAL MONETARY FUND
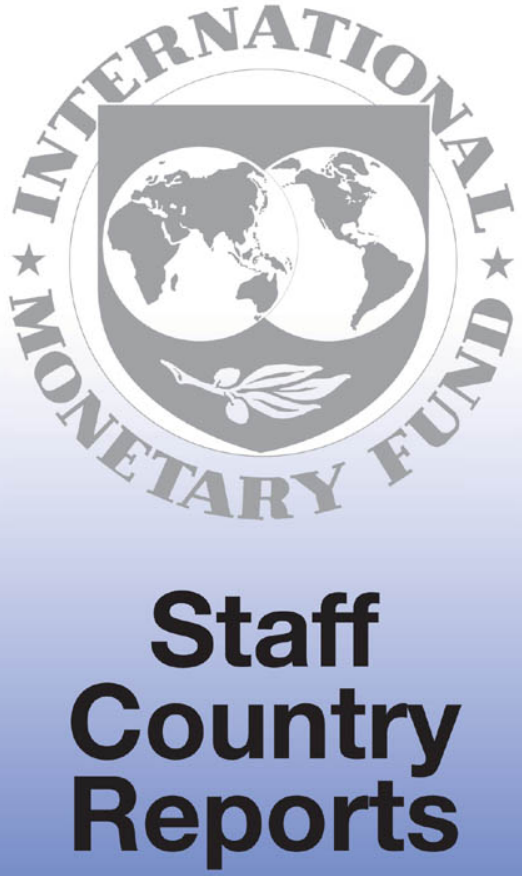


\section{Cyprus: 2011 Article IV Consultation-Staff Report; Supplement; Public Information Notice on the Executive Board Discussion; and Statement by the Executive Director for Cyprus}

Under Article IV of the IMF's Articles of Agreement, the IMF holds bilateral discussions with members, usually every year. In the context of the 2011 Article IV consultation with Cyprus, the following documents have been released and are included in this package:

- The staff report for the 2011 Article IV consultation, prepared by a staff team of the IMF, following discussions that ended on October 12, 2011, with the officials of Cyprus on economic developments and policies. Based on information available at the time of these discussions, the staff report was completed on November 3, 2011. The views expressed in the staff report are those of the staff team and do not necessarily reflect the views of the Executive Board of the IMF.

- $\quad$ An Informational Annex of November 3, 2011.

- A Public Information Notice (PIN) summarizing the views of the Executive Board as expressed during its November 18, 2011 discussion of the staff report that concluded the Article IV consultation.

- $\quad$ A statement by the Executive Director for Cyprus.

The policy of publication of staff reports and other documents allows for the deletion of market-sensitive information.

Copies of this report are available to the public from

International Monetary Fund • Publication Services

$70019^{\text {th }}$ Street, N.W. • Washington, D.C. 20431

Telephone: (202) 623-7430 • Telefax: (202) 623-7201

E-mail: publications@imf.org Internet: http://www.imf.org

\section{International Monetary Fund \\ Washington, D.C.}


This page intentionally left blank

(CInternational Monetary Fund. Not for Redistribution 


\section{INTERNATIONAL MONETARY FUND}

\section{CYPRUS}

\section{STAFF REPORT FOR THE 2011 ARTICLE IV CONSULTATION}

November 3, 2011

\section{KEY ISSUES}

Context: The economy is still burdened by the legacy of the imbalances that preceded the global crisis, including high leverage of the private sector and a real estate boom. A worsening outlook for global growth, unsettled financial conditions in the euro area, and the large exposure of Cypriot banks to Greece have created new obstacles to recovery. Meanwhile, deterioration in public finances has taken a toll on investor confidence. As a result of these factors, Cyprus has lost access to sovereign debt markets.

Policy challenges: The two key challenges are to put in place a large and credible fiscal consolidation that will reverse the increase in the public debt ratio and help restore investor confidence; and to ensure that the banks and their supervisors are well-prepared to respond to possible adverse developments. Even with these actions, it may take time to regain market access, and covering public financing needs in the period ahead will be challenging.

Policy response: The authorities are focused on implementing strong fiscal consolidation measures that would culminate in a balanced budget by 2014 , and on closely monitoring developments in the financial sector while stepping up their contingency planning. They are hopeful that they will be able to borrow from non-market sources, which would provide a bridge until they can regain market access. 
Approved By Ajai Chopra and Thomas Dorsey
Discussions took place in Nicosia during September 29 - October 12, 2011. Staff representatives comprised W. McGrew (mission chief), M. Dao, A. Simone (all EUR), R. Llaudes (SPR), M. Saiyid (MCM), and A. Weber (FAD). E. De Vrijer (EUR) joined the mission from October 7. Ms. Barendregt (OED) also attended the meetings.

\section{CONTENTS}

BACKGROUND 4

A. Pre-Crisis 4

B. Impact of Crisis $\underline{7}$

CURRENT VULNERABILITIES AND OUTLOOK $\underline{8}$

A. Fiscal Policies and Financing $\underline{12}$

POLICY DISCUSSIONS $\underline{17}$

A. Fiscal Policies and Financing___ 18

B. Financial Sector _ $\underline{20}$

C. Structural Reforms $\quad \underline{21}$

STAFF APPRAISAL $\underline{24}$

\section{TABLES}

1. Selected Economic Indicators, 2005-2016 $\underline{34}$

2. Fiscal Developments and Projections, 2005-2016__ $\underline{35}$

3. Public Sector Debt Sustainability Framework, 2006-2016 __ $\underline{36}$

4. Balance of Payments, 2005-2016___ 37

5. External Debt Sustainablity Framework, 2006-2016___ 38

6. Core Financial Soundness Indicators for Deposit Takers 2007-2011___ $\underline{39}$

\section{FIGURES}

1. Short-Term Indicators $\underline{26}$

2. Economic Indicators, 2004-2012_ 27

3. Financial Indicators _ $\underline{28}$

4. Fiscal Sector _ 29

5. Public Debt Sustainability: Bound Tests___ $\underline{30}$

6. External Sector__ 31

7. External Debt Sustainability___ $\underline{32}$ 


\section{BOXES}

1. Savings and Investment $\underline{6}$

2. The Housing Market $\underline{9}$

3. Competitiveness and Structural Issues $\underline{11}$

4. Structure of Cypriot Banking System $\underline{16}$ 


\section{BACKGROUND}

\section{A. Pre-Crisis}

1. Before the $\mathbf{2 0 0 8}$ crisis, Cyprus enjoyed a long period of high growth, low unemployment, and sound public finances.

The unemployment rate reached a low of 3.6 percent in 2008, with rapid wage and employment growth attracting an inflow of foreign workers. The main growth drivers were services exports, including financial, legal, accounting, and shipping services, which were attracted by an educated English-speaking workforce, low corporate tax rates, double-tax treaties with strategic partner countries, a stable macroeconomic environment, and Cyprus' favorable geographic location. Although declining in relative terms, tourism contributed 10 percent of GDP in 2008. Meanwhile, the public debt ratio was well below the euro area average at 48 percent of GDP at end-2008.

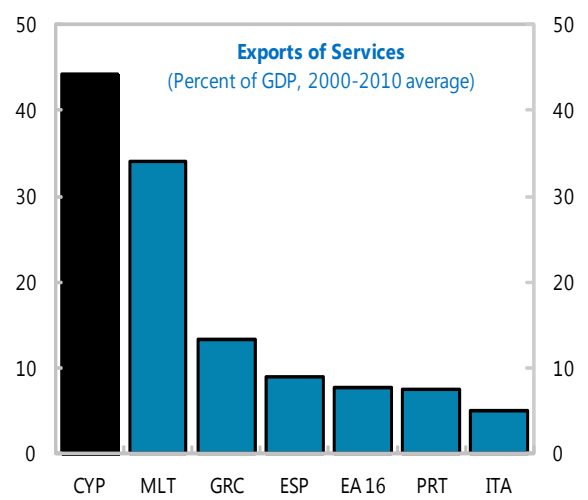

Sources: Statistical Office of the European Communities; and IMF staff calculations.

\section{However, vulnerabilities were} building in the form of widening external shortfalls, rapid credit growth, a real estate boom, and the large exposure of Cypriot banks to Greece. Current account deficits, which had previously been modest and mostly covered by FDI, started to widen after EU accession in 2004, reflecting a sharp drop of private savings (Box 1). The current account deficit hit a peak of 17 percent of GDP in 2008, which was largely financed by inflows of nonresident deposits to the banking system and external borrowing by banks. Rapid credit growth fueled a housing boom. Meanwhile, strong domestic demand, supported by foreign financing, contributed to rapid wage increases in excess of productivity gains.
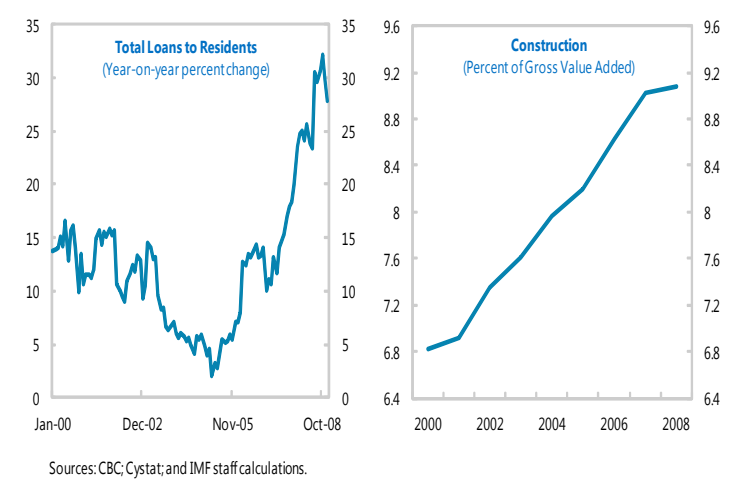

Sources: CBC; Cystat; and IMF staff calculations. 


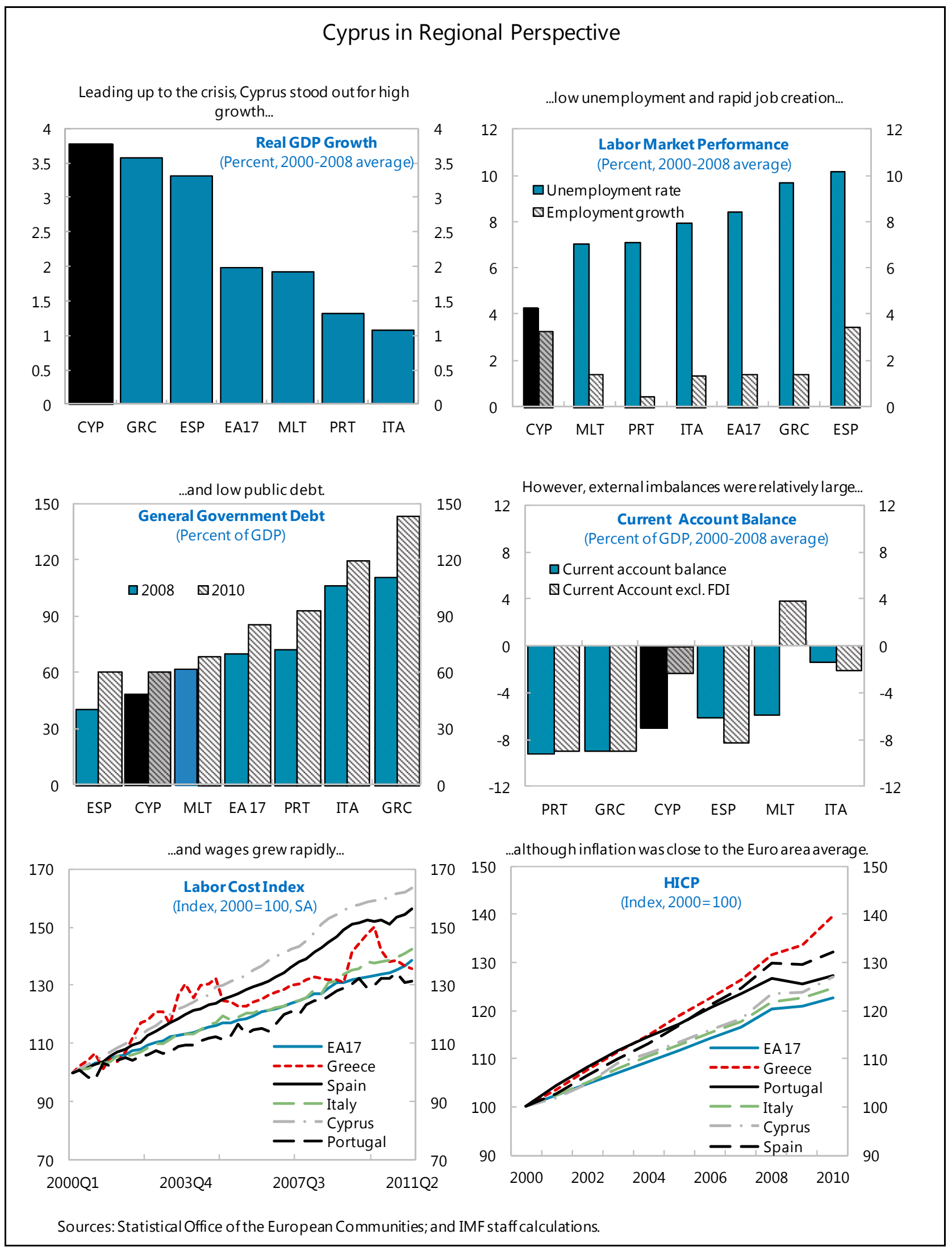




\section{Box 1. Savings and Investment}

After EU accession in 2004 and the run-up to adopting the euro in 2008, savings declined sharply, contributing to the rapid increase in the current account deficit. This likely reflected optimism about growth prospects as a full-fledged member of the euro area, as well as the easy availability of external credit that also led to lower savings in other peripheral euro area countries. Between the accession year of 2004 and the onset of the financial crisis in 2008, the saving rate dropped from 15 to 7 percent of GDP. Meanwhile, the investment rate increased from about 19 to 23 percent of GDP between 2004 and 2008, also contributing to the current account deficit. The private sector accounted for most of the saving decline and investment increase, while public saving and investment stayed largely constant.

Almost all of the increased investment between 2004 and 2008 went into the construction sector (investment in construction increased by 3.5 percent of GDP, while investment in machinery and equipment increased by only 0.3 percent of GDP). Much of the construction boom was driven by foreign demand for vacation homes (especially from the UK).
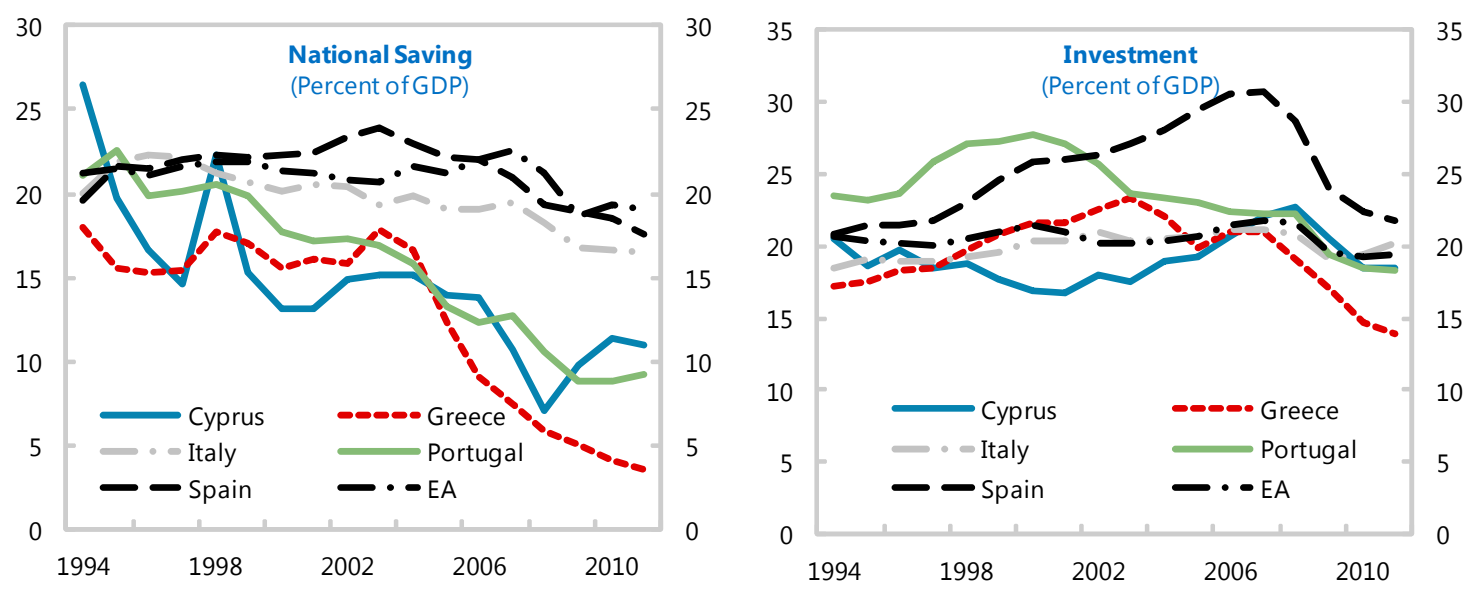

Sources: IMF, WEO, April 2011; and IMF staff calculations.
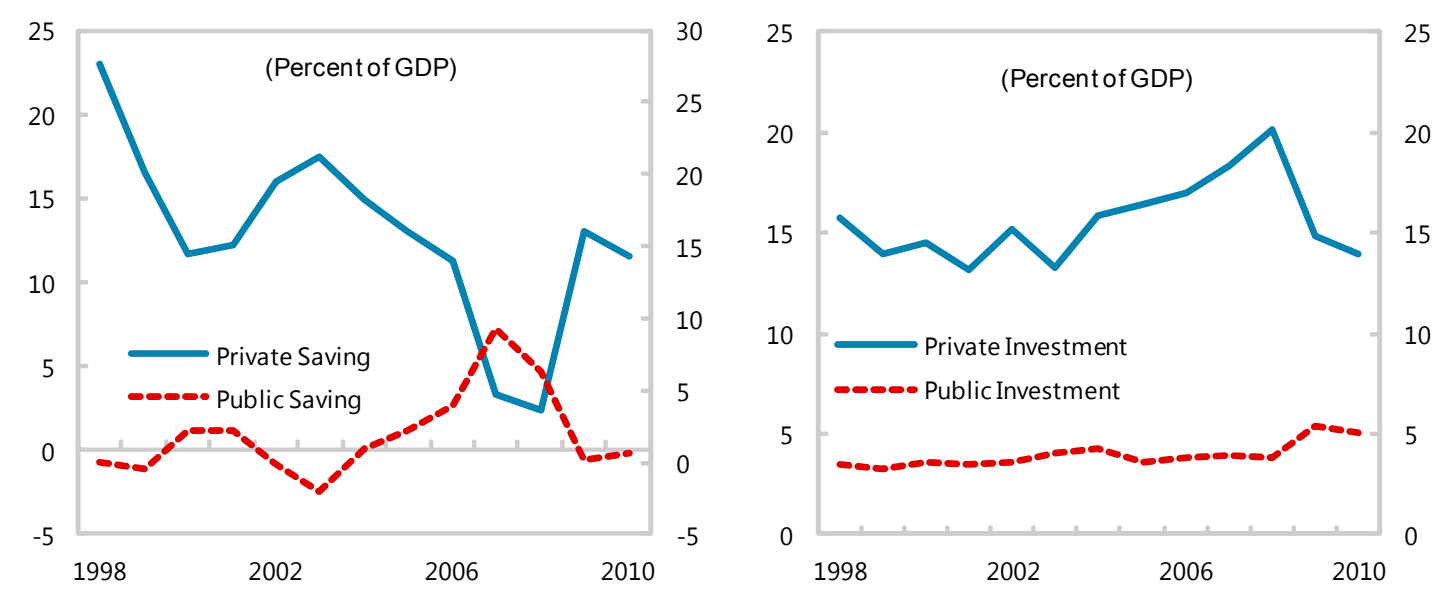

Sources:IMF, WEO; AMECO; and IMF staff calculations. 


\section{B. Impact of Crisis}

3. The crisis hit Cyprus through a drop in services exports and an abrupt slowdown in construction, whose impact was softened by a large fiscal expansion. Cyprus experienced the mildest recession in the euro area in 2009, with a drop in GDP of 1.9 percent. A sizable fiscal stimulus played a major role in cushioning demand. The relatively low reliance on manufacturing exports (which are more cyclical than service exports) and on wholesale bank funding also softened the impact of the crisis on exports and credit growth. Nonetheless, the recession triggered a sharp fall in consumption and a significant increase in unemployment. Growth recovered modestly in 2010, despite the dampening effects of increasing unemployment and high household leverage. Contraction in the construction sector and weak tourism remained important drags on the economy.

\section{The current account deficit adjusted} sharply, but remained at high levels compared to other euro areas countries. The current account deficit improved from 16.8 to 7.5 percent of GDP between 2008 and 2009, mainly due to weaker import demand and lower commodity prices. It remained stable in 2010, as a recovery of services exports was offset by a weaker goods balance due to higher oil prices. FDI provide the main source of financing over 2009-10, covering 65 percent of the current account deficit.

\section{The fiscal deficit deteriorated} sharply in $\mathbf{2 0 0 9}$ due to both structural and cyclical reasons, and narrowed somewhat in 2010 as a result of one-off factors and a small revenue package. A stimulus package of 4 percent of GDP was implemented in 2009 to cushion the impact of the crisis. The main measures were permanent increases in wages and salaries (1.6 percent of GDP), social transfers (1.6 percent of GDP), and public investment (1.4 percent of GDP). Automatic stabilizers were also allowed to operate, and a sharp decline ( 2.5 percent of GDP) in construction/real estate related revenues was largely accommodated. The result was a swing from a surplus in 2008 to a deficit of close to 6 percent of GDP in 2009. In 2010, one-off central bank-related revenues ( 0.5 percent of GDP), and a hike in petroleum excises and tax compliance measures ( 0.5 percent of GDP), contributed to a modest narrowing of the deficit.

Fiscal Indicators

\begin{tabular}{lrrr}
\hline & 2008 & 2009 & 2010 \\
\hline Overall balance & 0.9 & -5.9 & -5.3 \\
Cyclically adjusted fiscal balance & -0.2 & -5.6 & -4.8 \\
Structural fiscal balance & -2.2 & -5.9 & -5.3 \\
Output gap & 2.8 & -0.8 & -1.2 \\
\hline
\end{tabular}

Source: IMF staff estimates. 


\section{CURRENT VULNERABILITIES AND OUTLOOK}

\section{Financial conditions have} deteriorated rapidly since late 2010 , to the point where Cyprus is now effectively shut out of long-term sovereign debt markets.

Starting in late 2010, ratings agencies launched a series of downgrades and investors increasingly focused on the large exposure of the country's banks to Greece. Conditions worsened over the summer in tandem with adverse Greek developments and fiscal slippage in Cyprus. By mid-2011, 10-year government bond yields exceeded 10 percent and Cyprus had lost access to long-term sovereign debt markets. Meanwhile, bank stock prices plummeted, with the Cyprus Stock Exchange index (in which the three large banks account for over 90 percent of market capitalization) down 61 percent to date in 2011.

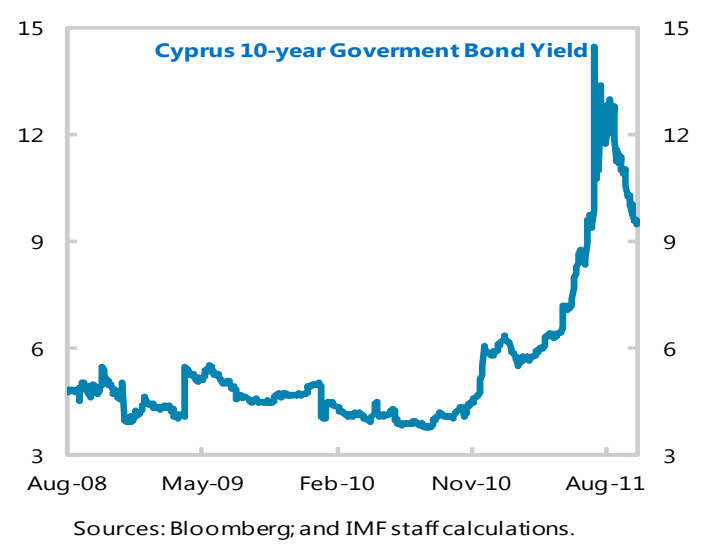

7. The destruction of a key power plant in July and its political fallout deepened the sense of economic uncertainty. On July 11 , a huge cache of confiscated munitions stored at a military base exploded, causing significant loss of life and destroying the next-door Vassilikos power plant, which supplied half the island's power. Reconstruction costs estimated at $€ 300-700$ million and are expected to be covered by the power company and insurance proceeds. The fallout included rolling blackouts in the summer months, with adverse effects on output and government revenues, and a weakening of support for the government. In early August, the President appointed a new cabinet, including a new finance minister. However, the centrist DIKO party left the governing coalition, leaving the ruling left wing AKEL party with a minority in parliament.

\section{Growth is expected to be zero in} 2011. The gradual recovery that started in 2010 was derailed by the loss of production and confidence stemming from the destruction of the power plant and weaker external demand, as well as increasing uncertainty and tighter financial conditions related to worsening prospects in Greece. The construction sector continues to retrench from the excesses leading up to the crisis. House prices and rents have been on a declining trend since the market peaked in 2008 and show no sign of recovery so far (Box 2). Tourism is one of the few bright spots, with revenues up 16 percent through August and on track to regain its 2008 level. 


\section{Box 2. Cyprus: The Housing Market}

The housing market in Cyprus experienced a boom over 2006-08. The central bank price index shows an increase of over 50 percent over that period, followed by a decline of 12 percent. Buyers from abroad contributed to the run-up and subsequent drop, with the UK accounting for, 70 percent of foreign buyers. Since end-2008, weak UK (and global) growth and the depreciation of the pound against the euro have depressed foreign demand.

The future development of housing prices will have an important impact on demand and growth of the broader

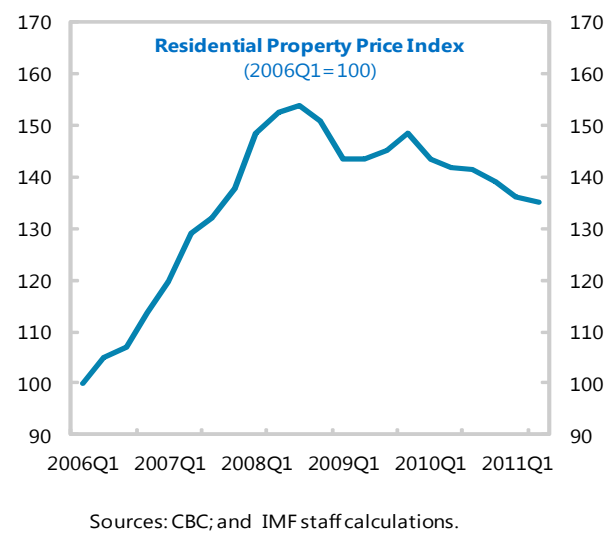
economy, as well as on bank balance sheets. Evidence on whether housing prices remain overvalued and subject to further correction is mixed. On two common indicators, the price-to-rent and the price to per capita GDP ratios, Cyprus does not exceed the European median ${ }^{1}$.
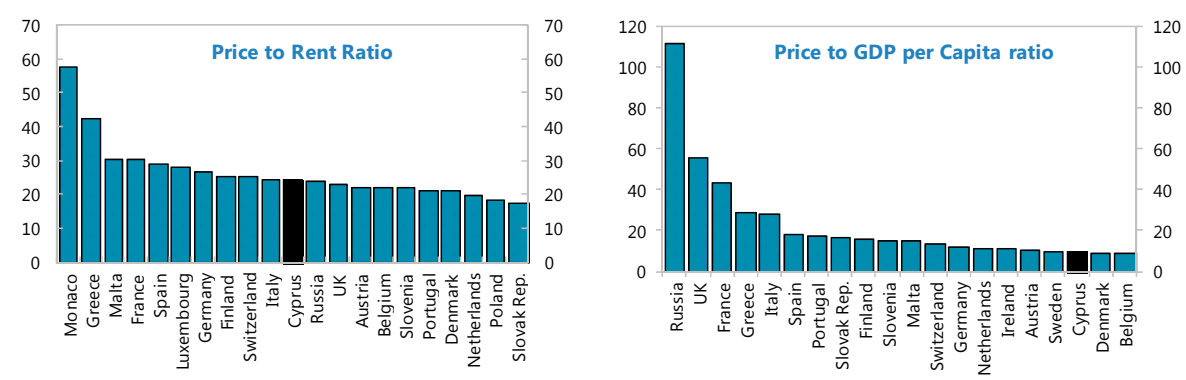

Source: Global Property Guide, October 2011

Another approach is to model the equilibrium housing price, which shows some overvaluation. We adopt the approach used in the fall 2004 WEO, which estimated the determinants of house prices in advanced countries using a dynamic panel model. Fundamental factors that were found to drive house prices are affordability (price-toincome ratio), income per capita, short-term interest rates, credit growth, population growth, and stock prices. Assuming that at the beginning of 2006 house prices in Cyprus were in line with economic fundamentals, their

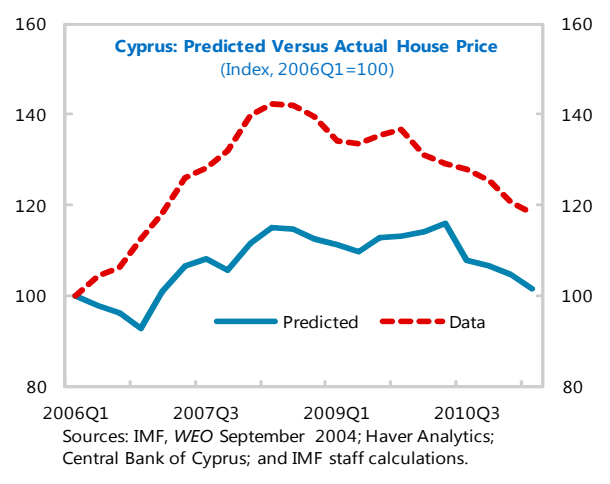
subsequent path follows qualitatively the same direction as predicted by the model, but with significantly higher increases. This methodology suggests prices may have remained overvalued in mid-2011 relative to their fundamental value, despite over two years of declines.

${ }^{1}$ House prices and rents are for a 100 square metres residential housing unit in premier locations of the most important city of each country. 


\section{Staff projects an economic} contraction of 1 percent in 2012 and a gradual recovery in outer years. The key drivers behind the expected downturn include yet tighter financial conditions as banks curtail their lending (or even shrink their balance sheets) in order to preserve capital and liquidity buffers; the negative short-term impact of fiscal adjustment measures; and a worsening growth outlook in the euro area and beyond.

Unemployment is expected to peak at $81 / 2$ percent in 2012 , while inflation is projected to decline to $2 \frac{1}{2}$ percent due to stabilization of commodity prices and subdued demand. Domestic demand is expected to recover over the medium term as both internal and external conditions normalize.

\section{The current account deficit is} projected to narrow further in 2011-12. The dampening impact of slow growth on imports, together with strong tourism (including a 50 percent increase in visitors from Russia), are expected to more than offset the impact of higher energy prices in 2011. As a result, the current account deficit is expected to decline from 7.8 percent of GDP in 2010 to 7.2 percent in 2011. The deficit is projected to narrow further in 2012, as the expected downturn depresses domestic demand, fiscal adjustment raises public sector savings, and commodity prices ease. Service exports are projected to remain subdued with only modest further gains in tourism receipts and sluggish shipping and international business services due to a worsened external environment. Box 3 provides an assessment of competitiveness.

\section{The downside risks to growth are}

sizable. A key risk to the baseline projection arises from developments in the euro area. If financial turbulence were to intensify and prospects for Greece to worsen, this could have a large impact on Cypriot banks, leading to even tighter financial conditions with negative implications for confidence and demand. Further, an adverse shock to world trade would affect Cyprus through services exports, which account for close to half of GDP. Finally, the fiscal consolidation planned for 2012-13 could have a larger than anticipated contractionary impact. If these risks were to materialize, 2012 growth could be considerably lower than the baseline projection. 


\section{Box 3. Competitiveness and Structural Issues}

Standard price-based real exchange rate measures show modest appreciation since 2000, with unit labor cost (ULC) based measures showing more significant appreciation. The overall ULC appreciation in Cyprus was higher than the euro area average. However it was broadly in line with other peripheral euro area countries, albeit with less downward flexibility around the period of the crisis. In particular, the ULC-based exchange rate for the manufacturing sector appreciated more than elsewhere. The manufacturing sector is small (currently at 7 percent of GDP) and has decreased as the economy has transitioned towards specialization in services, and the ULC-based appreciation may have helped to speed that transition.
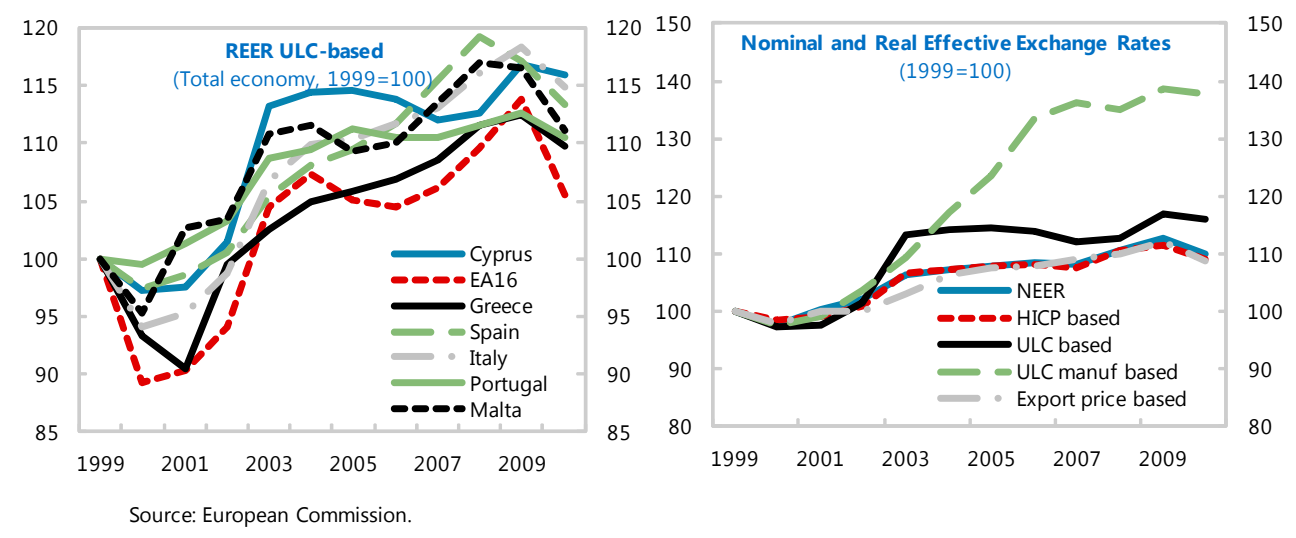

\section{CGER estimates suggest that the} real exchange rate is modestly overvalued. For the last decade, the real appreciation has been associated with persistent current account deficits above the norm predicted by economic fundamentals. CGER-based estimates suggest that the real exchange rate is overvalued by CGER estimates

\begin{tabular}{lrrr}
\hline & $\begin{array}{r}\text { Macroeconomic Equilibrium real } \\
\text { balance }\end{array}$ & $\begin{array}{r}\text { Purchasing } \\
\text { exchange rate }\end{array}$ & power parity \\
\hline CAB gap1/ & -2.8 & --- & --- \\
REER gap 2/ & 9.9 & 9.2 & 8.5 \\
\hline
\end{tabular}

Source: IMF staff estimates.

1/ Difference between actual current account balance (CAB) and the estimated equilibrium $C A B$ in percent of GDP (the medium term average). 2/ Percentage difference between the actual and the estimated equilibrium REER (the medium term average).

9 to 10 percent. Although Cyprus

is mostly an exporter of services rather than goods, staff analysis shows that the real exchange rate plays a similar role in both goods and services exports (see Selected Issues Paper). 


\section{A. Fiscal policies and Financing}

\section{Fiscal Policies}

\section{The government has launched a new} initiative aimed at reversing fiscal slippage and restoring market confidence. Staff projects that the deficit will widen from 5.3 percent of GDP last year to 7 percent in 2011 , bringing public debt to 68 percent of GDP, due to cyclically weak revenues and the failure to contain spending. To reverse the slippage, the government has announced fiscal savings targets of $€ 150$ million ( 0.8 percent of GDP) in 2011, €650 million (3.6 percent of GDP) in 2012, and $€ 400$ million (2.2 percent of GDP) in 2013. Its stated goals are to reduce the fiscal deficit to 2.8 percent of GDP in 2012 and achieve a balanced budget by 2014 .

- Parliament passed a first package of measures in late August that the authorities estimate will yield savings of $€ 109$ million in 2011 and $€ 152$ million in 2012. Main measures include an increase in the permanent contribution of 4.25 percent by public sector workers toward their pensions, an increase in the withholding tax on interest income from 10 to 15 percent, and a flat levy on businesses. The government has also closed the public service pension system to new employees (who will participate instead in the national pension system).

- A second package of measures was sent to Parliament in mid-October. According to the authorities, it would largely achieve the remaining savings targeted for 2012 but would leave the bulk of 2013 and 2014 savings for future legislation. Key measures include an increase in the VAT rate from 15 percent (the lowest in the EU) to 17 percent, a 6-month freeze of cost of living adjustments (COLA) for public servants (in addition the government will seek consensus by end-2011 on a permanent reform of the COLA that aims to achieve further fiscal savings), and improved targeting of social transfers based on income criteria. The authorities also announced that they would take additional measures in the event that realized fiscal savings from the measures fall short of the targeted amounts.

\section{The proposed measures would be an} important step towards addressing the high public sector wage bill and poorly targeted social transfers. At 15.4 percent of GDP in 2010, Cyprus has the largest public sector wage bill in the euro area. This was exacerbated in 2009 when wage increases pushed the wage bill up by 1.5 percent of GDP. Together with an array of poorly targeted social benefits (5.5 percent of GDP in 2010), these two categories consume 45 percent of total general government spending.

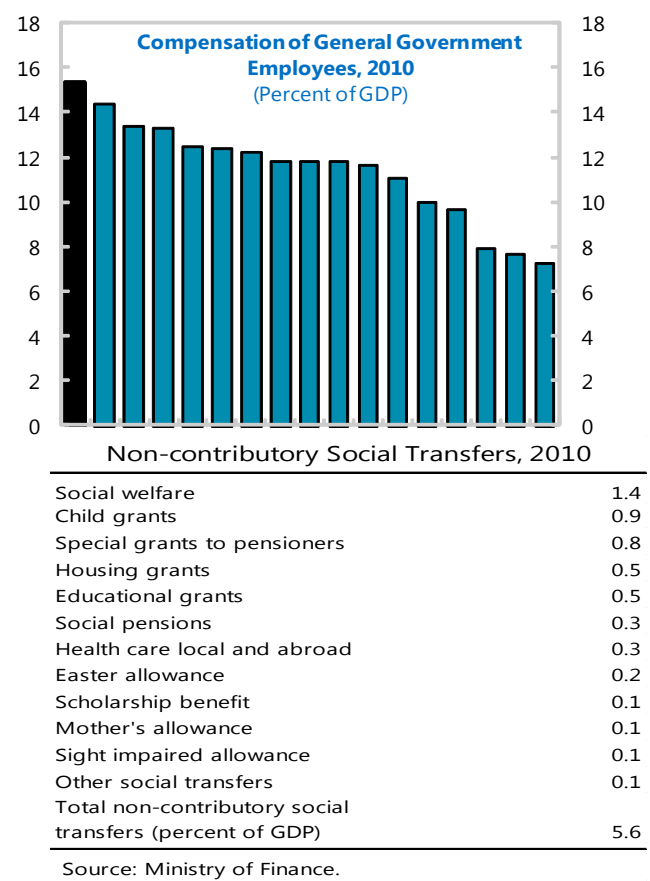


14. To support their fiscal consolidation goals and improve budget processes, the authorities plan to implement an agenda of structural fiscal reforms. These include:

(i) introduction of fiscal rules and a mediumterm budget framework into national legislation, consistent with EU directives; (ii) passage of a new public debt management law to improve debt and cash management; (iii) accounting and statistics reforms to expand coverage and increase timely data availability; (iv) strengthening revenue and expenditure forecasting to increase transparency and reduce biases in projections.

\section{Age-related outlays pose a major} long-term challenge to public finances. Pension expenditures, including both the national scheme managed by the Social Security Fund (SSF) and the pension scheme for public workers, are projected to become one of the highest in the euro area by 2050 . Health expenditures are also projected to increase by 1 percent of GDP by 2050 .

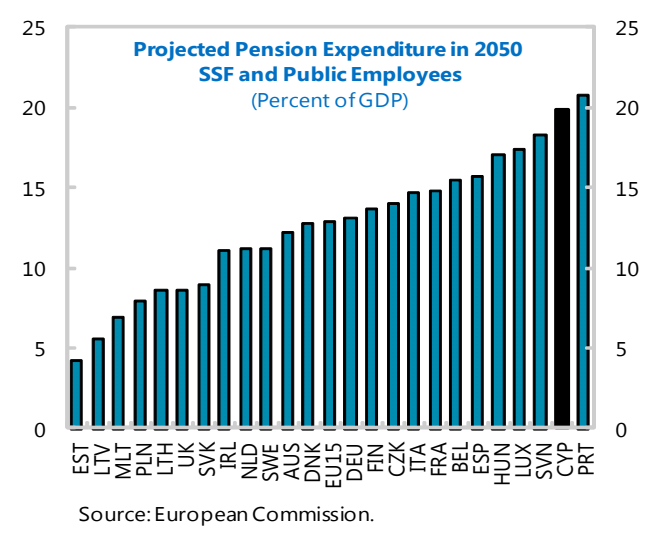

- The SSF deficit is estimated at about 0.5 percent of GDP in 2010 (excluding government contributions and interest on government debt held in pension fund reserves). Spending of the SSF is projected to increase by about 8 percentage points of GDP by 2050, to about 14 percent of GDP, as the population ages and the relatively new system matures.

Contributions from employees and employers are scheduled to rise by only about 3 percent of GDP, based on contribution increases scheduled to take place every 5 years from 2014 until 2039. As a result, transfers from the budget would need to increase by roughly 5 percentage points of GDP to meet SSF obligations.

- Public employee pension expenditures net of contributions are expected to increase from about 3 percent of GDP in 2010 to 5 percent of GDP in 2050, according to a recent actuarial study. The study suggests that an average contribution rate exceeding 40 percent would be needed to fully fund benefits through 2060, compared to the 5 percent employee contribution at present. The system remains generous by international standards even after recent reforms. Some groups (such as teachers and police) have low retirement ages. Benefits are based on the final salary instead of the career average, and a full pension can be accrued with fewer years of service than in the national scheme. Benefits are indexed to both general wage increases in the public sector and the consumer price index. In addition to the pension, workers receive a lump sum benefit at retirement that can exceed 5 times the annual pension.

\section{Financing}

16. Although the government has lost access to long-term sovereign debt markets, it will likely be able to meet remaining financing needs for 2011 through issuance of short-term debt and use of deposits. The amount of long-term 
debt maturing in the last quarter of 2011 is minimal. Provided the government can issue a small amount ( $€ 244$ million, or 1.3 percent of GDP) of net new short-term debt, and that it does not need to provide financial support to its banks, it will be able to meet its financing needs through year-end, with the help of deposits equaling 1.2 percent of GDP.

\begin{tabular}{|c|c|c|c|c|c|c|}
\hline \multicolumn{7}{|c|}{$\begin{array}{l}\text { Gross Financing Requirement, 2011-2013 } \\
\text { (Millions of euros and percent of GDP)1/ }\end{array}$} \\
\hline & $20112 /$ & Pct. of GDP & 2012 & Pct. of GDP & 2013 & Pct. of GDP \\
\hline Total Gross Financing Requirement (TGFR) & 583 & 3.2 & 3,208 & 17.4 & 3,973 & 21.3 \\
\hline Rollover of current obligations & 361 & 2.0 & 2,463 & 13.4 & 3,615 & 19.4 \\
\hline Deficit Financing after use of deposits & 221 & 1.2 & 745 & 4.0 & 359 & 1.9 \\
\hline Financing need assuming 100 percent rollover of short term debt & 244 & 1.3 & 1,967 & 10.7 & 2,732 & 14.7 \\
\hline \multicolumn{7}{|l|}{ Memorandum item: } \\
\hline Central Government Deposits (millions of euros) 3/ & 367 & $\ldots$ & $\ldots$ & $\ldots$ & $\ldots$ & $\ldots$ \\
\hline
\end{tabular}

Sources: Public Debt Management Office; Central Bank of Cyprus; and IMF staff estimates.

1/ Short term domestic paper refers to treasury bills, Long term domestic paper refers to Government Registered Development Stock, and Short term foreign instruments refer to Euro commercial paper and 1 year Eurobonds.

2/ Refers to the period October- December 2011.

3 / Balance as of September 23, 2011. A minimum balance of $€ 150$ million is normally kept as a liquidity cushion. $€ 210$ million were assumed to be used to cover the deficit financing needs in 2011.

\section{Government financing will be a} major challenge in $\mathbf{2 0 1 2}$ absent non market financing. Long-term debt maturities include a $€ 550$ million domestic bond maturing in January 2012 and a $€ 550$ million Eurobond maturing in February. Financing needed to cover all maturing long-term debt and the fiscal deficit in 2012 totals roughly $€ 2$ billion.

\section{B. Financial Sector}

\section{A large banking system with heavy exposure to Greece is a major vulnerability of the Cypriot economy. Bank assets total} $€ 152$ billion (835 percent of GDP), while assets of commercial banks with Cypriot parents are $€ 92$ billion (500 percent of GDP). Exposure of these banks to Greece totals $€ 29$ billion, or 160 percent of GDP, including both Greek government bonds and loans to Greek residents. They also hold $€ 1.6$ billion of Cypriot government bonds but minimal amounts of sovereign debt of other peripheral euro area countries.

19. The largest risk comes from commercial banks with Cypriot parents, although other banking groups also pose potentially significant risks (Box 4). NPLs at these banks have risen on both their local loan portfolios and their branches' Greek loan books, and provisioning ratios have declined. Only the non-collateralized portions of NPLs are provisioned, which leaves banks exposed to further losses in the event of significant declines in collateral value.

Non-performing Loan Ratios and Loan Loss Provisions

\begin{tabular}{lrrrr}
\hline & Dec-09 & Dec-10 & Mar-11 & Jun-11 \\
\hline NPLs at local banks 1/ & 9.8 & 12.1 & 12 & 13.9 \\
NPLs on loans in Greece & 7.8 & 11.1 & 12 & 13.9 \\
Provisions (consolidated, & & & & \\
pct. of all loans 90 days or \\
more in arrears)
\end{tabular}


Cyprus: Structure Of The Banking System (Billions of euros)

\begin{tabular}{|c|c|c|c|c|c|c|c|c|c|c|}
\hline & $\begin{array}{l}\text { Loans (net of } \\
\text { provisions) }\end{array}$ & $\begin{array}{l}\text { Cyprus } \\
\text { loans to } \\
\text { residents }\end{array}$ & $\begin{array}{l}\text { Cyprus } \\
\text { loans to } \\
\text { non- } \\
\text { residents }\end{array}$ & $\begin{array}{l}\text { Loans in } \\
\text { Greece }\end{array}$ & $\begin{array}{c}\text { Securities } \\
\text { and other } \\
\text { investments }\end{array}$ & $\begin{array}{l}\text { Of which: } \\
\text { sovereign } \\
\text { bonds }\end{array}$ & $\begin{array}{l}\text { Of which: } \\
\text { Greek } \\
\text { government } \\
\text { bonds }\end{array}$ & $\begin{array}{l}\text { Interbank } \\
\text { assets }\end{array}$ & $\begin{array}{c}\text { Total } \\
\text { assets }\end{array}$ & $\begin{array}{l}\text { Percentage } \\
\text { of GDP }\end{array}$ \\
\hline System & 91.4 & 43.2 & 17.8 & 23.4 & 28.7 & 14.7 & 7.2 & 24.8 & 152.0 & 835 \\
\hline Branches of foreign banks & 2.1 & 0.4 & 1.8 & 0.0 & 0.5 & 0.2 & 0.0 & 4.8 & 7.6 & 42 \\
\hline Subsidiaries of foreign banks & 16.5 & 6.1 & 10.4 & 0.0 & 11.5 & 4.0 & 2.4 & 6.4 & 35.3 & 194 \\
\hline Cooperative banks & 12.4 & 12.4 & 0.0 & 0.0 & 2.3 & 2.1 & 0.1 & 1.1 & 16.9 & 93 \\
\hline \multirow[t]{2}{*}{ Commercial banks } & 60.3 & 24.3 & 5.6 & 23.4 & 14.3 & 8.4 & 4.7 & 12.4 & 92.1 & 506 \\
\hline & Total deposits & $\begin{array}{l}\text { Cyprus } \\
\text { deposits } \\
\text { from } \\
\text { residents }\end{array}$ & $\begin{array}{l}\text { Cyprus } \\
\text { deposits } \\
\text { from non- } \\
\text { residents }\end{array}$ & $\begin{array}{l}\text { Deposits } \\
\text { raised in } \\
\text { Greece }\end{array}$ & & $\begin{array}{l}\text { Liabilities } \\
\text { to parent } \\
\text { banks }\end{array}$ & $\begin{array}{c}\text { Interbank } \\
\text { Liabilities (ex } \\
\text { parent) }\end{array}$ & $\begin{array}{l}\text { Capital } \\
\text { and } \\
\text { reserves }\end{array}$ & $\begin{array}{c}\text { Total } \\
\text { liabilities }\end{array}$ & $\begin{array}{l}\text { Percentage } \\
\text { of GDP }\end{array}$ \\
\hline System & 93.8 & 37.3 & 33.8 & 17.3 & & 21.1 & 18.6 & 14.2 & 152.0 & 835 \\
\hline Branches of foreign banks & 5.5 & 0.8 & 4.6 & 0.0 & & 0.9 & 1.0 & 0.2 & 7.6 & 42 \\
\hline Subsidiaries of foreign banks & 10.0 & 4.2 & 5.8 & 0.0 & & 20.2 & 2.7 & 1.9 & 35.3 & 194 \\
\hline Coops & 13.8 & 13.6 & 0.2 & 0.0 & & 0.0 & 1.1 & 1.5 & 16.9 & 93 \\
\hline Commercial Banks & 64.5 & 18.6 & 23.1 & 17.3 & & 0.0 & 13.8 & 10.6 & 92.1 & 506 \\
\hline
\end{tabular}

Source: Central Bank of Cyprus (June 30, 2011).

20. Cypriot banks face significant capital needs to meet the new European Banking Authority requirements. The EBA calculations released on October 26 indicate that Cypriot banks require additional capital estimated at $€ 3.6$ billion (20 percent of GDP) on a preliminary basis to attain a 9 percent core Tier 1 capital ratio and create a buffer against mark-to-market losses on their sovereign debt holdings. An updated diagnostic could possibly reveal larger capital needs. 


\section{Box 4. Structure of Cypriot Banking System}

Banks can be grouped into four main categories: Cypriot commercial banks (with domestic and international operations), foreign branches, foreign subsidiaries, and savings cooperatives.

- Commercial banks with Cypriot parents hold $€ 92$ billion (505 percent of GDP) in assets, dominated by three large banks (Bank of Cyprus, Marfin Popular Bank, and Hellenic Bank) which together account for 97 percent of total assets of this group. They have large foreign operations through branches and subsidiaries, primarily through the Marfin and Bank of Cyprus branches in Greece. They hold $€ 23$ billion (130 percent of GDP) in loans to Greek residents and $€ 5$ billion of Greek government bonds. Loans to residents outside Greece through foreign affiliates (including in south-east Europe, Russia, Ukraine, and the UK) total $€ 7$ billion.

- Foreign branch assets total some $€ 8$ billion (42 percent of GDP). They are attracted to Cyprus largely for tax reasons and their interaction with the Cypriot economy is limited, as they receive minimal funding from and hold minimal claims on Cypriot residents. This low degree of interaction would likely help shield the Cypriot banking system from problems at these branches (or their parents), although reputational risks to the broader banking sector are possible.

- Foreign subsidiary assets total $€ 35$ billion (195 percent of GDP). Similar to foreign branches, they are located in Cyprus largely for tax and regulatory reasons. Their interaction with the Cypriot economy is only a share of their total assets, with $€ 4$ billion in deposits from Cypriot residents and $€ 6$ billion in loans to residents. They are predominantly Greek (Alpha, Eurobank, Piraeus, and NBG) and also include the subsidiary of a Russian state bank. They largely rely on parent funding and their parents hold much of the credit risk on their assets. However, the risk to Cyprus would be larger than for foreign branches due to their greater interactions with the Cypriot economy and their legal status as subsidiaries participating in the national deposit insurance scheme.

- Some 100 savings cooperatives hold $€ 17$ billion (92 percent of GDP) in assets. Their assets are dominated by loans to residents and they are funded predominantly by resident deposits. Cooperatives are regulated separately from banks, by the Authority for Supervision and Development of Cooperative Societies. 
21. Funding pressures are another significant vulnerability. Cypriot banks rely mostly on deposits for funding, with a loan-todeposit ratio of 93 percent. Capital market refinancing needs are low, at $€ 550$ million in 2011-13, and reliance on interbank financing is modest. However, three sources of funding vulnerability stand out.

- First, non-resident deposits (NRD) in Cypriot banks (excluding deposits raised abroad by foreign affiliates) are $€ 23$ billion (125 percent of GDP), most of which are short-term at low interest rates. These could prove unstable in the event of further confidence shocks. This risk is partly mitigated by the 70 percent liquid asset requirement against the $€ 12$ billion in NRD in foreign currency), and the 20 percent requirement for the $€ 11$ billion in euro-denominated NRD).

- Second, $€ 17$ billion in deposits collected in the Greek branches of the three largest
Cypriot-owned banks could be subject to outflows in response to difficult conditions in Greece. Outflows in the first half of 2011 were close to $€ 3$ billion (nearly 15 percent of the total), although a portion of these returned to the Cypriot parents as NRD. While the system as a whole could handle continued moderate outflows, individual banks could face liquidity shortages.

- Third, funding pressures could also arise from loss of access to ECB liquidity. The ECB currently provides some significant liquidity to the system, most of which must eventually be replaced by market funding. Moreover, further market losses on Greek (as well as Cypriot) government debt would reduce the value of collateral eligible for ECB funding. Should Cyprus be downgraded to below investment grade, its government securities could no longer be eligible as collateral for ECB refinancing facilities under current rules.

debt maturities, presented a major challenge. The authorities broadly shared the staff assessment. 


\section{A. Fiscal Policies and Financing}

23. Staff argued that a large, frontloaded, and credible fiscal adjustment, in the context of a multi-year framework, was essential to restore sustainability of public finances and regain market access.

- Size of adjustment. Staff advised that Cyprus does not have the option of backloading adjustment to protect growth, given its lack of access to financing and the need to restore confidence. The size of adjustment in 2012-13 needs to be sufficient to put the budget on a firm path towards balance by 2014, with a substantial down payment in 2012. Staff agreed with the authorities that their planned fiscal savings -6.6 percent of GDP over 2011-13, of which 3.6 percent of GDP is slated for 2012-strike an appropriate balance between the need for a sizable adjustment and the need to avoid fiscal cuts so large that they would undermine growth prospects and create negative dynamics for investor confidence and bank balance sheets. Under the staff baseline scenario, these adjustments would stabilize the public debt ratio in 2013 and reduce it to 60 percent of GDP by 2016 .

- Credibility. Staff emphasized the importance of being conservative in estimates of the fiscal savings from adjustment measures and identifying additional contingency measures in case savings fall short of target. The need for conservative estimates is all the more important in light of the projected outcome for this year, which compares unfavorably to the deficit target of 4 percent of GDP in the 2011 budget. While endorsing the authorities' targets for fiscal savings over 2011-13, staff viewed the authorities' projection that this would reduce the fiscal deficit to below 3 percent of GDP in 2012 as too optimistic. First, it takes as a starting point a deficit of 6.5 percent of GDP in 2011, whereas in staff's view the outcome will be about 7 percent of GDP (the difference is due to more conservative staff assumptions on the savings yield of adjustment measures). Second, it is based on a projection of 0.2 percent growth in 2012, whereas staff expects a contraction due to financial sector deleveraging, weak external demand, and the negative short-term impact of fiscal cuts on output. A more realistic deficit path over the next 3-4 years, underpinned by well-defined fiscal savings, would enhance credibility. Moreover, staff viewed implementation risks around the planned measures as considerable-both from potential watering down of the measures and

Deficit Projections Assuming Realization of Official Targets for Fiscal Savings in 2012-2013

\begin{tabular}{lcrr}
\multicolumn{4}{c}{ (Percent of GDP) } \\
\hline & 2011 & 2012 & 2013 \\
\hline Authorities & 6.5 & 2.8 & 0.5 \\
Staff & 7.0 & 4.0 & 1.9 \\
\hline
\end{tabular}

Sources: Ministry of Finance; and IMF staff estimates. because they could fail to achieve the targeted savings.

- Multi-year framework. The government should move quickly to pass into legislation specific measures in the context of a credible multi-year consolidation plan for 2012-14. After passage of the second 
package of measures needed to secure the targeted savings in 2012, additional measures need to be adopted to achieve the $€ 400$ million in savings targeted for 2013 and to balance the budget in 2014 . Up-front measures rather than promises of future actions are needed to establish credibility and regain investor confidence. In the event that economic growth recovers more quickly than expected and revenues exceed projections, excess revenues should be used to reduce the deficit further.

\section{Staff recommended that additional measures to reach the $\mathbf{2 0 1 3}$ fiscal targets should be predominantly expenditure-based. International evidence} suggests that expenditure-based consolidation is more reliable in securing savings. In addition, it is important to preserve a favorable tax climate to protect Cyprus' appeal as an international business center, and Cyprus has ample remaining room for reducing the public wage and pension bill and targeting social transfers (especially after the large increases in 2009). Specific areas should include freezing the COLA for two years as an interim measure pending more fundamental reform of the COLA system; eliminating automatic salary increments; targeting social transfers based on income criteria; and reforms to the national and public employee pension systems. While achieving $€ 400$ million with these measures should be feasible, staff recommended preparing for an additional 1 point increase in the VAT rate to 18 percent and savings from reprioritizing public investment as a contingency in case measures related to current expenditure do not yield the intended savings.

Selected Economic Indicators under the Baseline (B) and Downside (D) Scenarios

(Percent of GDP, unless otherwise indicated)

\begin{tabular}{|c|c|c|c|c|c|c|c|c|c|c|}
\hline & \multicolumn{2}{|c|}{2012} & \multicolumn{2}{|c|}{2013} & \multicolumn{2}{|c|}{2014} & \multicolumn{2}{|c|}{2015} & \multicolumn{2}{|c|}{2016} \\
\hline & B & $\mathrm{D}$ & B & $\mathrm{D}$ & B & $\mathrm{D}$ & B & $\mathrm{D}$ & B & $\mathrm{D}$ \\
\hline Real GDP growth (percent) & -1.0 & -3.0 & 0.8 & -2.0 & 2.0 & 1.0 & 2.8 & 2.5 & 3.0 & 3.5 \\
\hline Inflation (percent) & 2.4 & 1.0 & 2.3 & 0.5 & 2.2 & 1.0 & 2.1 & 1.5 & 2.1 & 2.0 \\
\hline General government fiscal deficit & -4.0 & -5.9 & -1.9 & -5.8 & 0.0 & -4.4 & 0.0 & -3.6 & 0.0 & -3.1 \\
\hline Public debt & 67.5 & 72.0 & 68.7 & 81.0 & 66.3 & 84.7 & 63.5 & 85.4 & 60.4 & 84.1 \\
\hline
\end{tabular}

Source: IMF staff estimates.

25. In the event that downside risks to growth materialize, staff recommended keeping the magnitude of the planned 2011-13 fiscal savings unchanged, while taking measures to safeguard fiscal sustainability in the outer years. Additional consolidation measures in a weaker economy should be avoided provided sufficient funding is available, since they would further depress demand and growth, which could have an adverse impact on investor confidence. In an illustrative scenario with lower growth and inflation but the same fiscal savings, the public debt ratio would peak at 85 percent of GDP in 2015. To protect fiscal debt sustainability, it would thus be important to implement consolidation measures over the longer term, including deeper reforms to the national and public employee pension systems. 


\section{The government expressed its} commitment to achieving fully the savings targets, and to taking additional measures in the event of shortfalls. They agreed that delays in taking effective adjustment measures had resulted in the loss of valuable time and damaged credibility. They remained more optimistic than staff on both the 2011 deficit outcome and 2012 growth, and thus believed they would be successful in reducing the deficit to below 3 percent of GDP in 2012, en route to a balanced budget by 2014 . The authorities were mindful of the need to move quickly on measures to secure fiscal savings in 2013-14, and emphasized the need for social dialogue to achieve the needed consensus. They were sympathetic to the benefits of expenditure-based consolidation and believed

\section{B. Financial Sector}

\section{Staff encouraged the authorities to take measures to strengthen the capacity of the banking system to weather adverse shocks including by:}

- Strengthening crisis management procedures and engaging in contingency planning. This includes priority passage of legislation to give the authorities adequate powers to provide financial support through fast-track procedures and to resolve banks if needed (under current law the authorities lack powers to liquidate or sell insolvent banks without shareholder approval or going through lengthy legal procedures); planning for various scenarios of capital and liquidity shortages in different parts of the banking system, including foreign branches of Cypriot banks and foreign subsidiaries operating in that there was significant room for further rationalization of public spending.

\section{Staff highlighted the vulnerability} posed by the loss of access to sovereign debt markets. Even with full implementation of the authorities' fiscal adjustment plans, it would take time to regain market access in light of uncertain external economic and financial conditions and the need to establish a track record of successful consolidation. The authorities were confident that they would receive a low interest loan of $€ 2.5$ billion from Russia before the end of the year. In their view, this would allow them to meet a substantial portion of their 2012 gross financing needs and provide time to implement fiscal consolidation and restore market confidence.
Cyprus; and coordinating closely with foreign supervisors and EU banking authorities.

- A plan to achieve higher capital levels and to ensure adequate funding. The authorities need to work with the banks to agree on a plan to raise the preliminary estimate of $€ 3.6$ billion in capital by June 2012 to meet the recently announced strengthened EBA capital requirements. Potential sources include new equity investments, conversion of existing hybrid capital to eligible convertible capital, restricting profit distributions and bonuses, and sale of assets such as foreign subsidiaries. It remains unclear whether it will be possible to raise the additional capital from private sources. If not, the envisaged recapitalization would require 
government or official external support. Before injecting capital into a bank, the authorities should make a positive assessment of it solvency. The authorities should also evaluate bank liquidity needs and work with EU banking authorities, as necessary, to secure access to term funding.

29. The authorities acknowledged that there were gaps in their powers to resolve and recapitalize banks. They are in the process of drafting legislation to remedy these gaps, and asked for technical assistance in this endeavor (in particular on legislation to provide bank resolution powers) from the Fund. In response, a Fund technical assistance team visited Cyprus the week of October 24.

\section{Staff recommended that} cooperatives should be subject to the same regulatory and supervisory regime as commercial banks. While the cooperatives do not have significant exposure to Greek or other foreign borrowers, they should be monitored closely in light of their large size (over 90 percent of GDP) and elevated NPL rates. The authorities should review the

\section{Structural Reforms}

\section{Pension Reform}

\section{Staff recommended that the} authorities initiate a reform of the national pension system to put it on a sustainable long-term financial footing. While the fiscal burden of the pension system is limited at present, it will grow over time. Action at an early juncture can spread out necessary adjustments over time, making them easier to absorb. Staff recommended a number of regulatory and supervisory structure of the cooperatives and identify any disparities with the regime for commercial banks that could give rise to regulatory arbitrage or market distortions. Staff also reiterated its long-standing advice that supervision and regulation of banks and cooperatives should be unified, and that as an intermediate step the regulatory frameworks should be harmonized. Staff also called for greater transparency, including publication of the same data as available for commercial banks.

31. Staff discussed the outcome of the recent MONEYVAL (the financial action task force-style regional group of which Cyprus is a member) anti-money laundering and combating the financing of terrorism (AML/CFT) mutual evaluation report, with an emphasis on international cooperation and supervision. The report's recommendations pertaining to international cooperation are particularly important, given the size of the international services sector, and the potential for adverse spillovers on other economies.

reform options that could be explored, including (i) introducing an early retirement penalty; (ii) increasing the retirement age gradually to 67 years and linking it to increases in life expectancy; (iii) moving gradually towards indexing pensions to inflation only; and (iv) reducing the imbalance between contributions and benefits by gradually adjusting the pension accrual rate and accelerating planned contribution rate increases for employees and employers (see 
Selected Issues Paper). The authorities welcomed the staff analysis and agreed on the importance of reforms to ensure the long-term sustainability of the system. They explained that they were preparing to release an actuarial study that would evaluate the system's long-term finances, which would provide an opportunity to explore reform options.

\section{Staff welcomed the introduction of} higher contributions by public sector workers towards their pensions and encouraged the authorities to pursue deeper reforms. To rationalize costs, staff recommended a set of reform options, including adoption of the same retirement age as the national scheme; a gradual extension of the period used to compute benefits to the full career average; a gradual move towards indexing pensions to the CPI; and a gradual phase-out of the lump sum benefit at retirement (See Selected Issues Paper).

\section{Structural Fiscal Reform}

\section{Staff encouraged the authorities to} push ahead on structural fiscal reforms to support the introduction of a medium-term budgetary framework. EU directives relating to the fiscal framework should be expeditiously implemented, including the one that mandates the introduction of fiscal rules in national legislation. Swift passage of national fiscal rules will signal the authorities' commitment to sound public finances, although a transition regime will be needed for their full implementation. Staff encouraged the authorities to improve core budget processes such as strengthening forecasting, simplifying budget classifications, and increasing the flexibility to reallocate spending across different categories, which would help to reduce the need for supplementary budgets (see Selected Issues Paper). Staff also advised reorganizing the revenue administration by combining the separate departments responsible for different taxes and strengthening the exchange of information. Finally, staff welcomed the authorities' intention to pass a new debt management law. The authorities agreed on the importance of structural fiscal reforms and indicated that they would seek Fund technical assistance in priority areas.

\section{Staff advised the authorities to improve the management of fiscal risks} from extra budgetary entities and PublicPrivate Partnerships (PPPs). In the short term this can be achieved by closely monitoring the finances of the largest extra budgetary entities by the Ministry of Finance. In the medium term, consideration should be given to divesting suitable entities, liquidating entities that are no longer needed, and bringing back into the budget entities that carry out government functions and lack adequate rationale for operating as autonomous entities. With respect to PPPs, staff recommended reform of the framework to ensure the proper evaluation of financial risks to the budget and to put in place procedures that empower the Ministry of Finance to stop PPP projects that do not meet appropriate standards (see Selected Issues Paper).

\section{Competitiveness}

\section{Reducing wage rigidities is the most important structural reform needed to} address the competitiveness challenge. The current crisis is an opportunity to undertake significant reform or even eliminate the cost of living adjustment system in the public sector (which would be expected to lead to reduced 
use of the COLA in the private sector). By linking wages automatically to inflation rather than productivity, the COLA reduces the flexibility of relative wage levels across different firms and sectors, which hinders the ability of the economy to adjust to variations in productivity or demand. At an economy-wide level, the COLA also impedes the flexibility of wages to adjust to shocks such as the 2008 financial crisis or commodity price swings. It also contributes to high public sector wage levels, which makes it more difficult for the private sector to attract skilled workers. For these reasons, few countries in the euro area have automatic adjustments mechanisms such as the COLA, and Fund staff has generally advised against their use.

\section{Cyprus has made some progress in} improving its regulatory environment, with more yet to be done. Cyprus ranks $40^{\text {th }}$ among 183 countries worldwide in the World Bank Ease of Doing Business indicator, and $47^{\text {th }}$ among 142 economies in terms of broader competitiveness as measured by the World Economic Forum's Global Competitiveness Report. Measures taken have included simplifying the administrative procedures to set up new business (one-stop shop). Further measures are needed to improve the business environment. Cyprus ranks only 39 out of 48 high income countries in the World Bank's Ease of Enforcing Contracts index, reflecting the numerous procedures and long waiting times to resolve disputes in court. Moreover, some key transport services are severely restricted in terms of working hours (e.g., ports, warehouses) or access to license to operate (e.g., trucks).

\section{Investment in R\&D and the rate of adoption of new technologies by businesses}

\section{are very low relative to other euro area} countries, including those with similar size and industry structure. Cyprus ranks low in terms of its capacity for innovation and $R \& D$, one of the dimensions of competitiveness defined by the Lisbon Strategy. ${ }^{1}$ Aggregate spending on $R \& D$, at 0.4 percent of GDP, is far below the EU target of 3 percent of GDP and is almost exclusively carried out by the public sector. Information and communication technologies usage by enterprises ranks among the lowest in the EU, according to survey data from Eurostat.

\section{Reforms to further improve the} business climate by reducing red tape and removing obstacles to technology upgrading would increase potential growth in the medium and long term. The authorities should identify the regulatory hurdles affecting the business environment discussed above and lay out appropriate reforms. They should explore what obstacles hinder more widespread technology adoption. Initial measures to support Cypriot businesses in their efforts to upgrade technology and enhance productivity have been included in the National Reform Program.

\footnotetext{
${ }^{1}$ According to the Lisbon Review 2010, Cyprus ranks $13^{\text {th }}$ out of $27 \mathrm{EU}$ countries in terms of overall competitiveness, but only 21th in terms of the subcategory Innovation and R\&D.
} 


\section{STAFF APPRAISAL}

40. The Cypriot economy faces a very difficult economic outlook as it confronts new external challenges while still working to overcome the legacy of the $\mathbf{2 0 0 8}$ crisis. Externally, the exposure of Cypriot banks to Greece and worsening prospects for external demand pose the main challenges. Domestically, the foremost challenge is to restore sound public finances, and to regain access to sovereign debt markets.

\section{The situation calls for immediate} action to reverse the widening fiscal deficits and put public debt on a downward path. The pace of adjustment must be ambitious but realistic to build credibility. If the economy evolves as anticipated under staff's baseline scenario, it should be possible to bring the deficit below 3 percent of GDP by 2013 . Measures should focus mostly on expenditure reductions, which are more durable and reliable than revenue increases. Priority areas for fiscal savings include containment of public sector wages and benefits and further improvements in the targeting of social transfers towards the less well-off, as well as a moderate increase in VAT rates. Fiscal savings should be based on conservative assumptions and implemented without slippage. These are preconditions for restoring confidence and ensuring the government can access markets to meet its financing needs.

\section{The government has set ambitious} targets that would deliver a large reduction in the deficit in $\mathbf{2 0 1 2}$ and a balanced budget within three years. This timeframe strikes an appropriate balance between the need for up-front savings and the benefits of avoiding an excessive contraction in demand. The government should now move quickly to pass into legislation specific measures, in the context of a credible multi-year consolidation plan, and prepare additional measures that can be rapidly put in place to address contingencies.

43. In view of unsettled external conditions, utmost vigilance and careful contingency planning are required for the financial sector. The authorities should require banks to put in place robust plans to achieve higher capital ratios consistent with new EBA requirements, and to identify and address potential liquidity needs. They should move quickly to enhance their powers so that they can take prompt corrective action to recapitalize or resolve banks, if necessary. To this end, passage of the bank framework law and amendments to the banking act, preferably at the same time, should be an immediate priority. Greater attention should be paid to cooperative credit institutions, to ensure that their regulation and supervision is on par with that for banks and to detect any problems at an early stage.

44. The top priority in the area of structural reform is to improve the flexibility of labor markets in order to improve the prospects for growth and employment. Containing public sector wages and benefits, sustained reductions in the size of public employment, and significant reform to the cost of living allowance mechanism will make an important contribution by increasing wage flexibility and augmenting the flow of highly qualified workers to the private sector.

45. Reforming the national pension scheme is key to long-term fiscal sustainability. Although the fiscal burden of 
the system is limited at present, it will grow quickly as the system matures. This is a good time to initiate reform of the system to ensure its financial equilibrium over the longer term. If reforms are agreed soon, they can be phased in gradually, avoiding the disruption that would result if they were postponed until the mounting costs of the system demand immediate action.

\section{Reform of budget institutions is needed to support fiscal consolidation while also promoting greater accountability, transparency, and efficiency of public finances. Key areas include introduction of a medium-term budgetary}

framework and the full implementation of EU fiscal framework directives, including the introduction of fiscal rules.

\section{The Cypriot economy faces large} risks that demand a strong policy response. Bold corrective actions can set the stage for resumption of economic growth, based on the underlying strengths of the economy, including a highly educated workforce and diversified international service economy.

48. It is proposed that the next Article IV consultation take place on the standard 12-month cycle. 
Figure 1. Cyprus: Short-Term Indicators
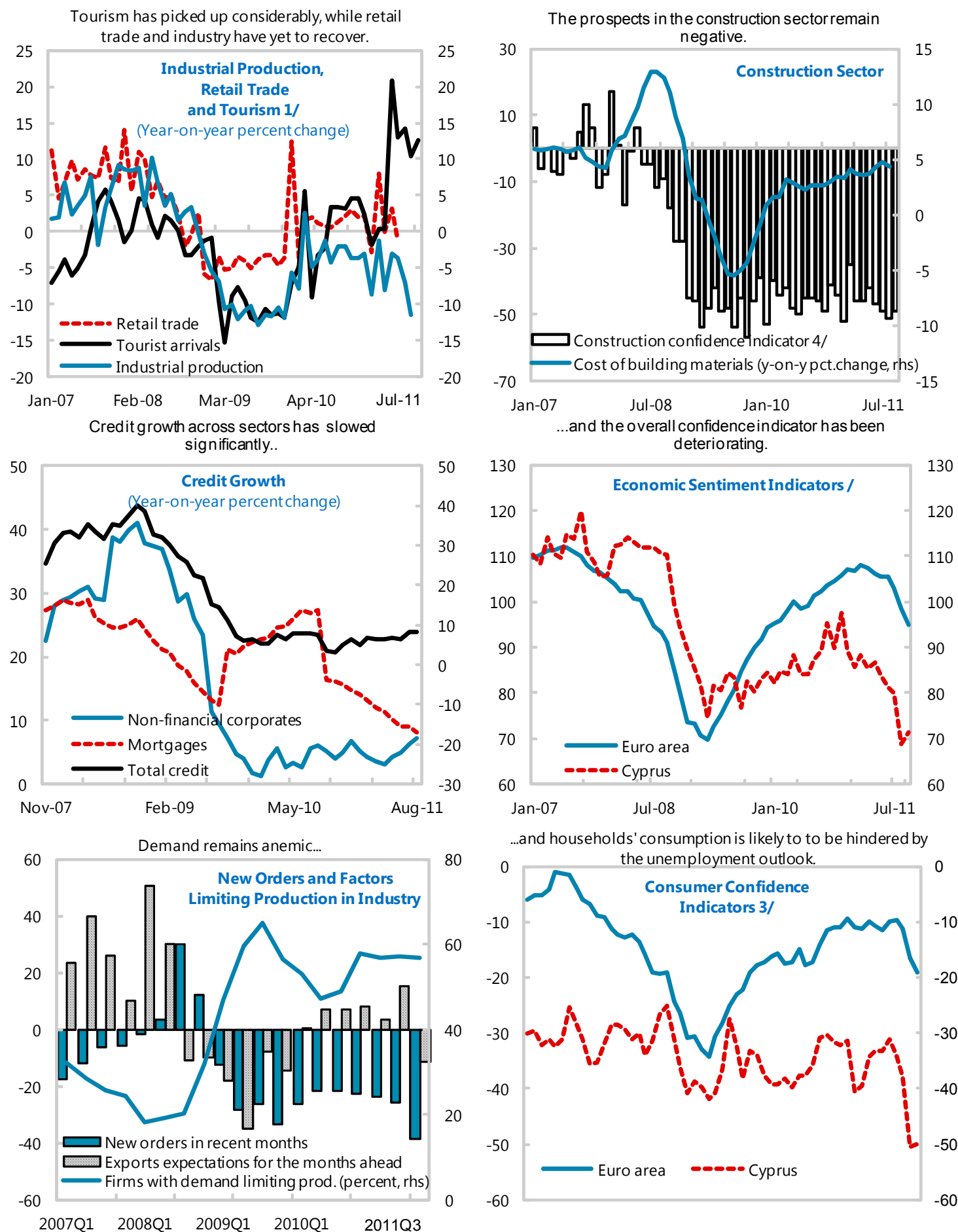

Sources: Cyprus Statistical Office; Central Bank of Cyprus, Cyprus Ministry of Finances, Eurostat, and European Commission. $1 /$ The industrial production and, and retail sales data as of July 2011 tourist arrivals data are as of August 2011.

2/Values greater than 100 indicate an above-average economic sentiment, whereas values below 100 indicate a below-average position.

3/All confidence indicators are balances, meaning the difference between the percentages of respondents that have positive and negative expectations for the next 12 months. A negative numbermeans that more respondents were pessimistic than optimistic. The higher the negative number, the more pessimistic the respondents are. 
Figure 2. Cyprus: Economic Indicators, 2004-2012
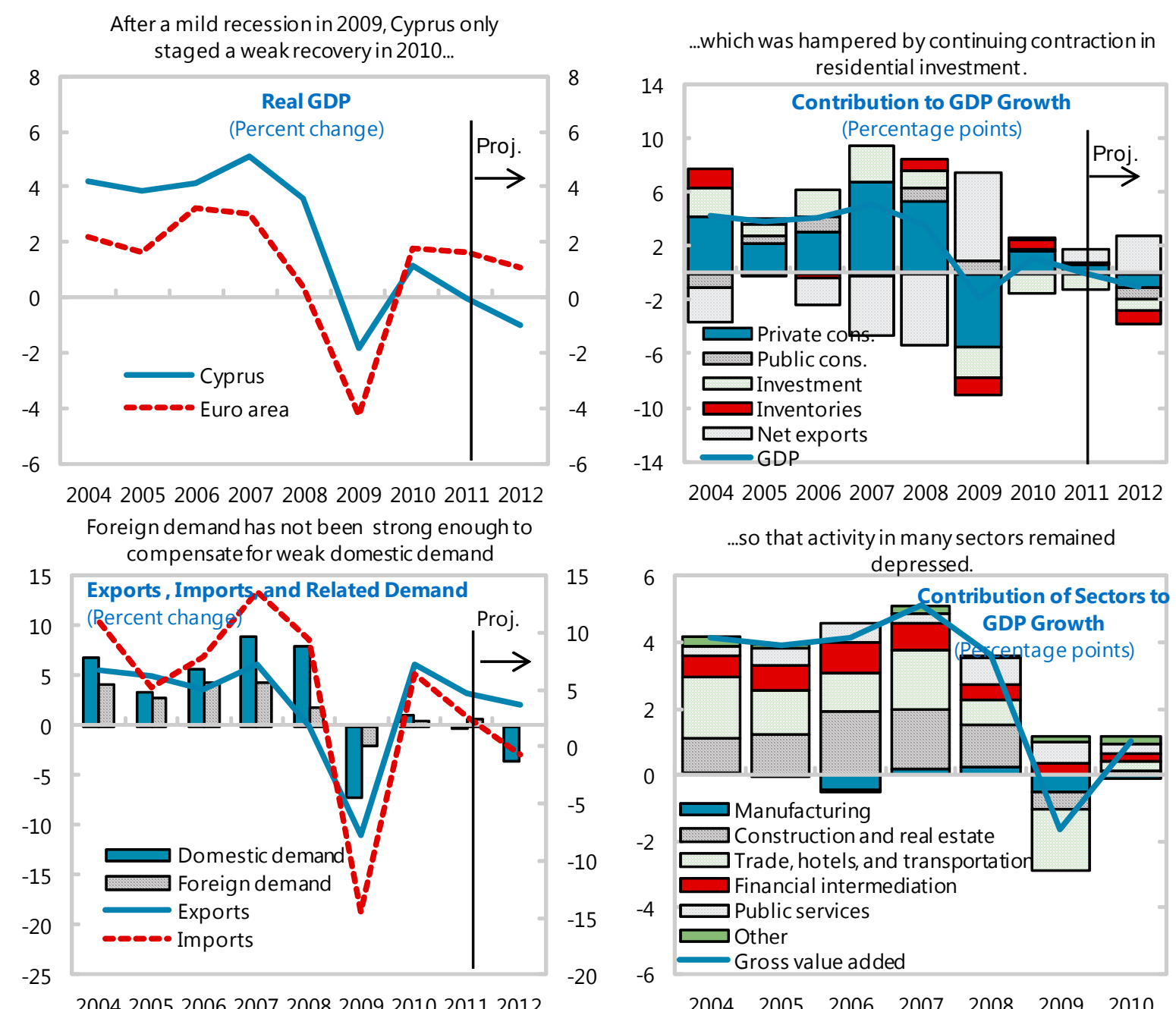

6

depressed.
Contribution of Sectors to 6

10

4

4
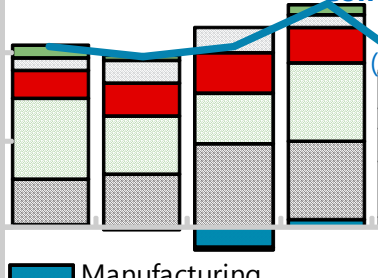
GDP Growth

5

0

$-5$

Manufacturing

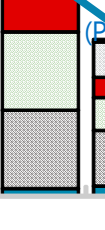

(Rercentage points)

4

2

$-10$

$-4$

Trade, hotels, and transportation

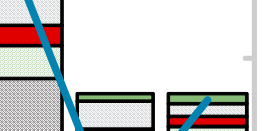

0

0

200420052006200720082009201020112012

The fiscal deficit widened, while the current account

30 deficit remained largely constant afterits 2009 fall.

Fiscal Balance, Debt and Current Account

Financial intermediation

$-4 \quad$ Public services

-6 Gross value added

$2004 \quad 2005 \quad 2006 \quad 2007 \quad 2008 \quad 2009 \quad 2010$

Private agents are highly leveraged, posing further risks to the recovery.

$\begin{array}{lllllll}0 & 100 & 200 & 300 & 400 & 500 & 600\end{array}$
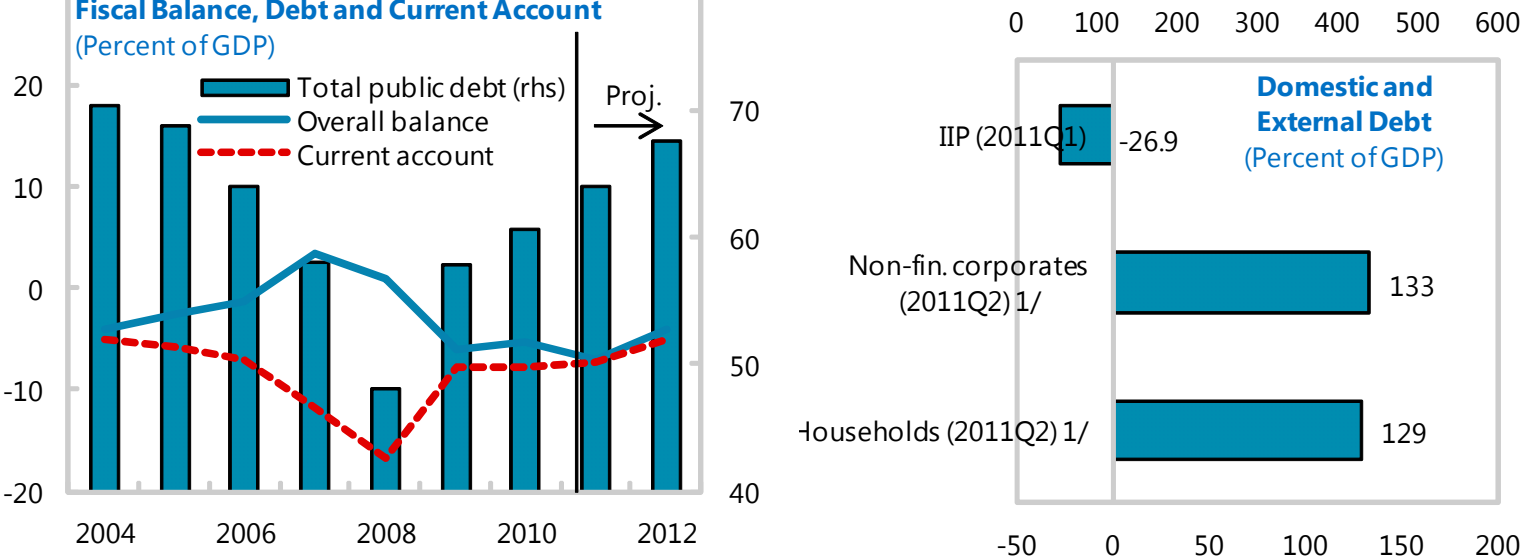

Sources: Cystat; IMFWEO; and IMF staff estimates.

1/ Includes bank loans to domestic residents. Non-financial corporate and household debt in gross terms. 
Figure 3. Cyprus: Financial Indicators
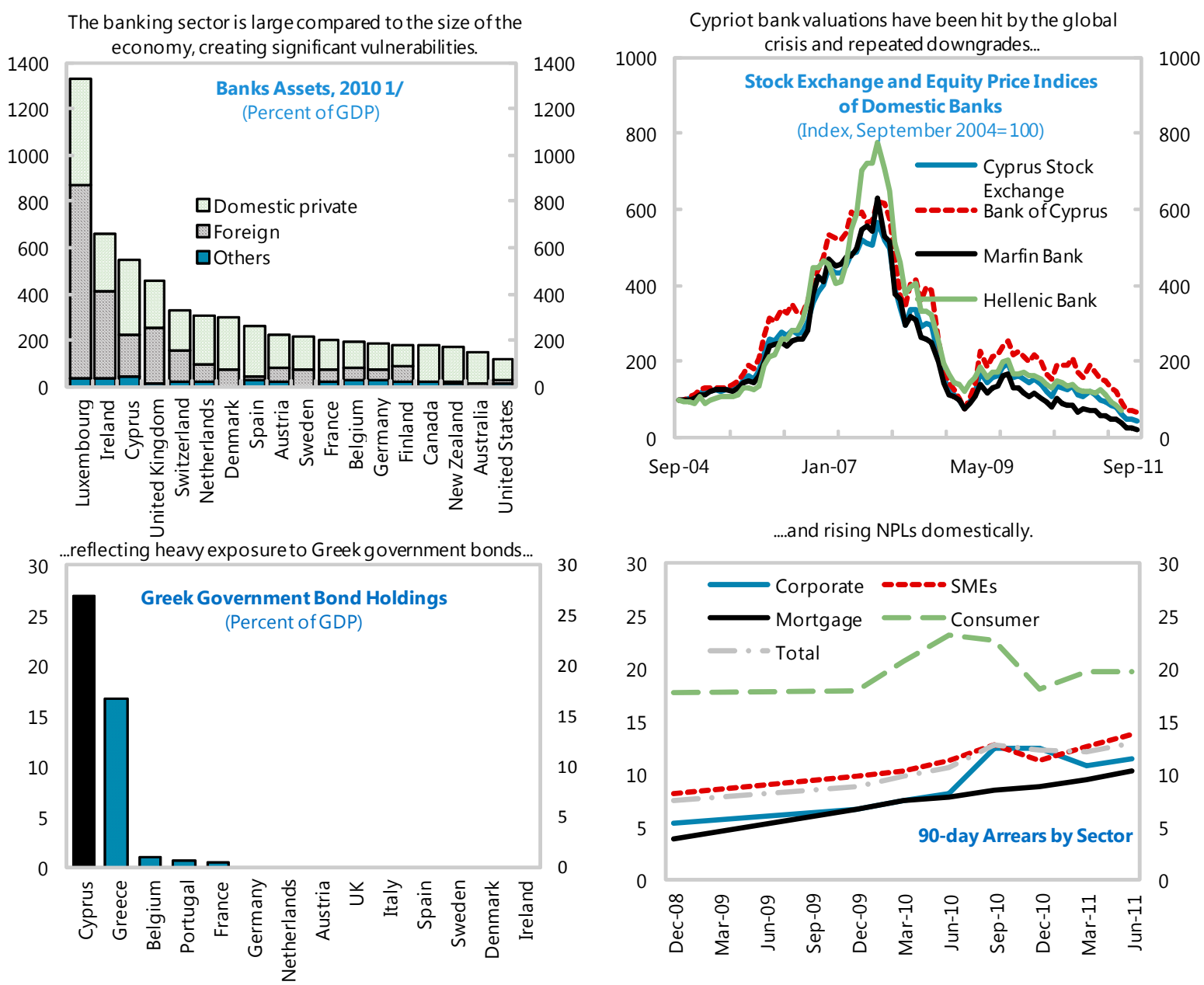

Competition with cooperatives and Greek banks
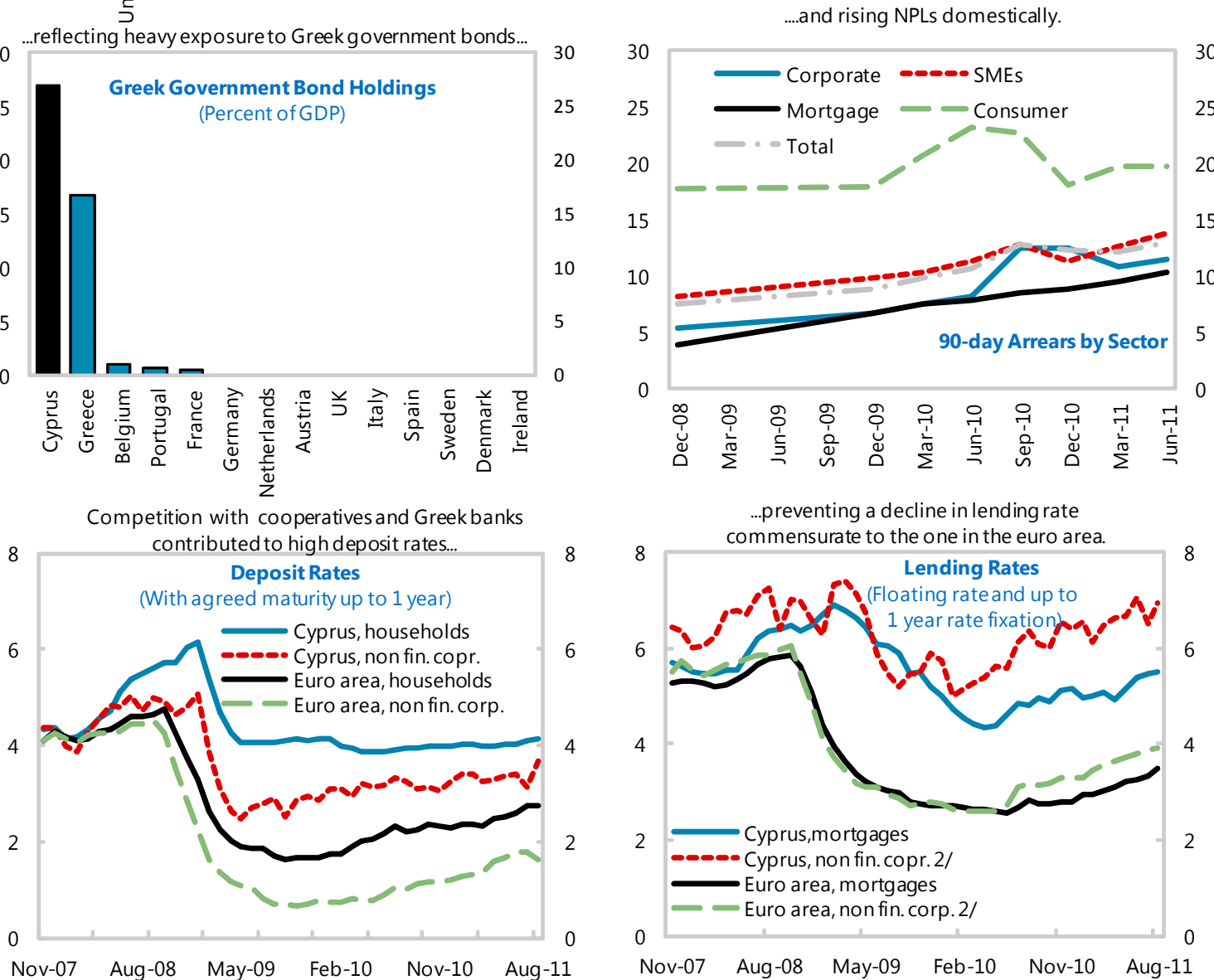

...preventing a decline in lending rate commensurate to the one in the euro area.

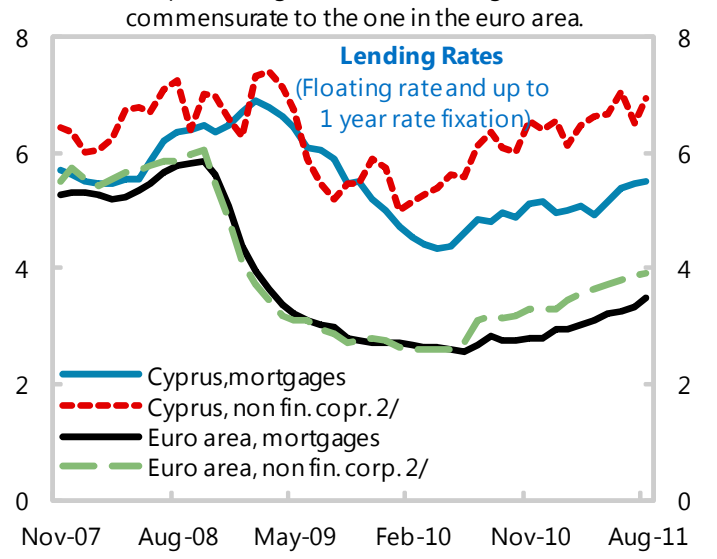

Sources: Bloomberg; Central Bank of Cyprus; ECB; IMF, IFS; and IMF staff calculations.

1 / Includes only the assets of the banks residing in side Cyprus.

2/ Average of rates for loans up to and over euro 1 million. Breakin EA data from July 2010. 


\section{Figure 4. Cyprus: Fiscal Sector}

(Percent of GDP)

The increase in the deficit in 2009-2010, due to fiscal stimulus and automatic stabilizers, has not been reversed.

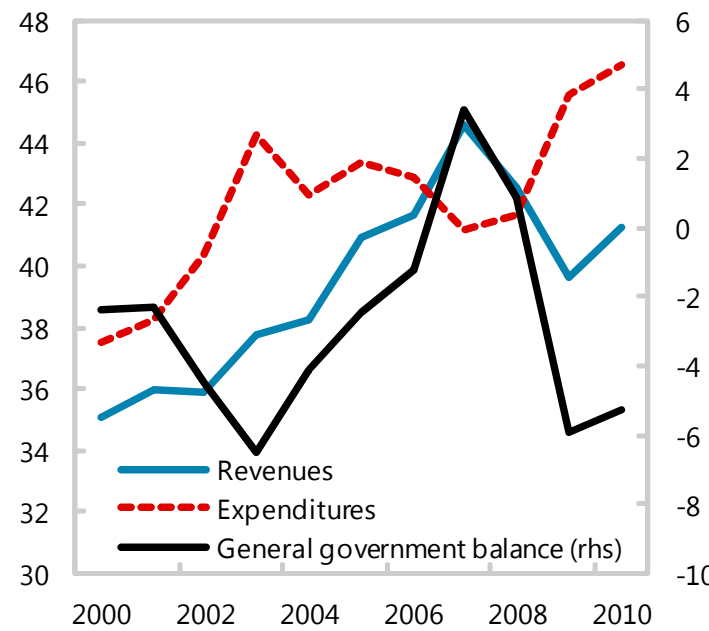

...while the wage bill and social transfers have continued to increase.

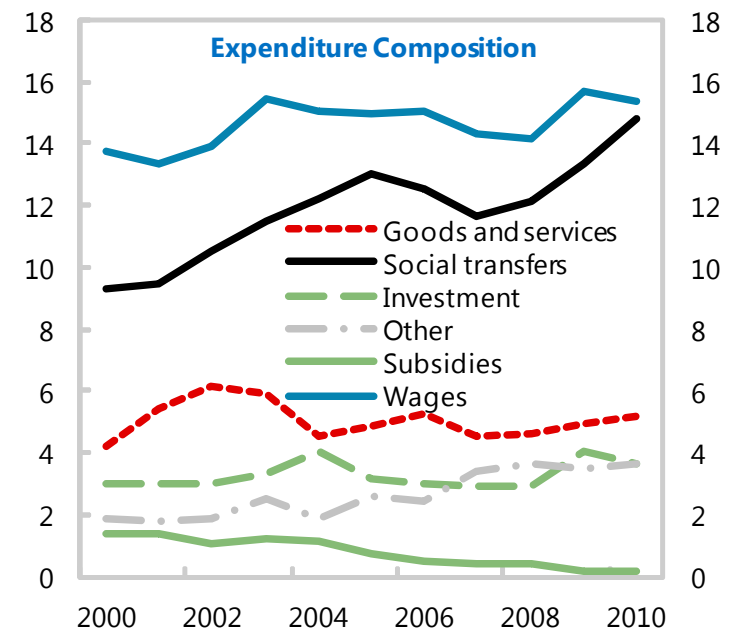

Both direct and indirect taxes declined considerably since 2008 due to falling revenues from construction and real estate...

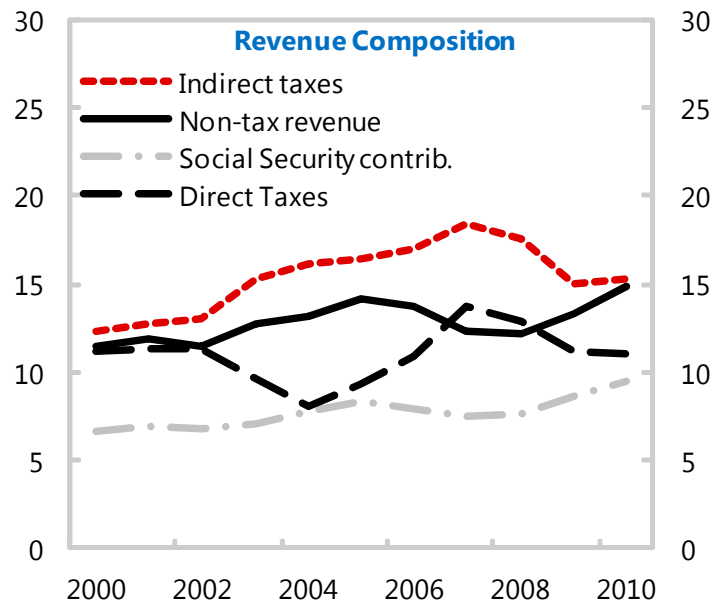

The fiscal impulse helped soften the drop in aggregate demand in 2009 but at the expense of a large permanentincrease in the structural balance.

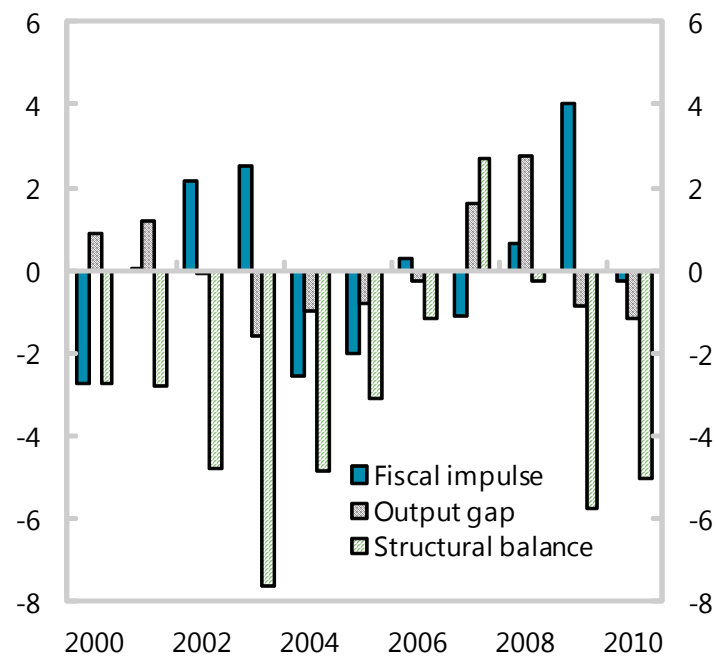


Figure 5. Cyprus: Public Debt Sustainability: Bound Tests 1/ 2/ (Public debt in percent of GDP)
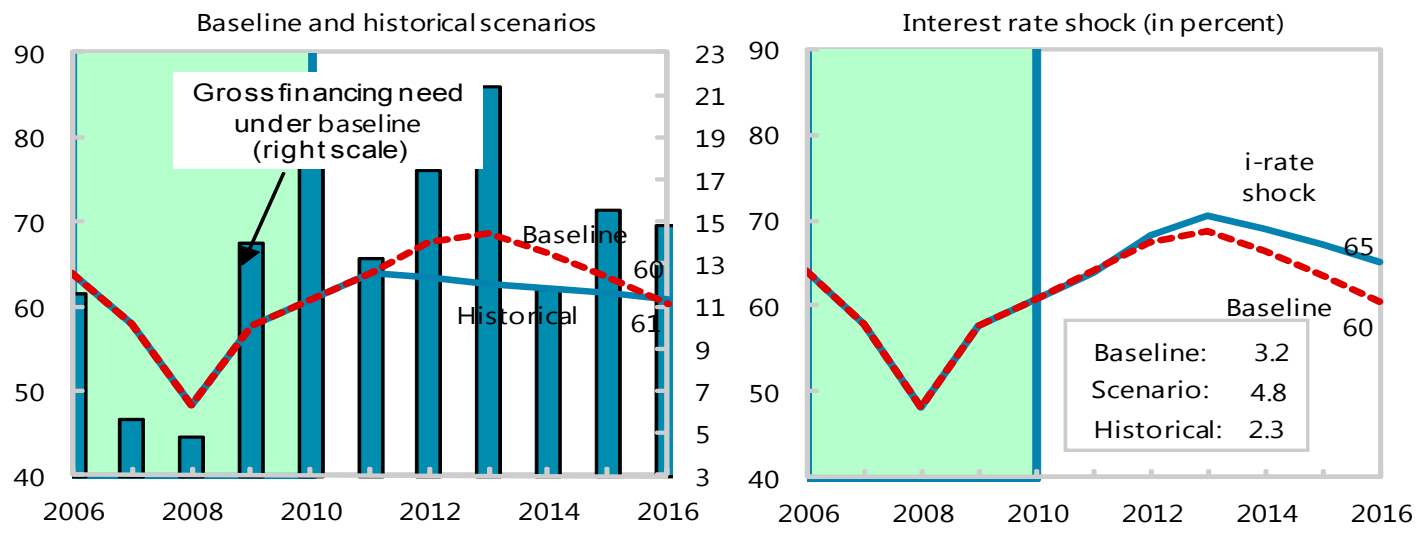

Growth shock (in percent peryear)

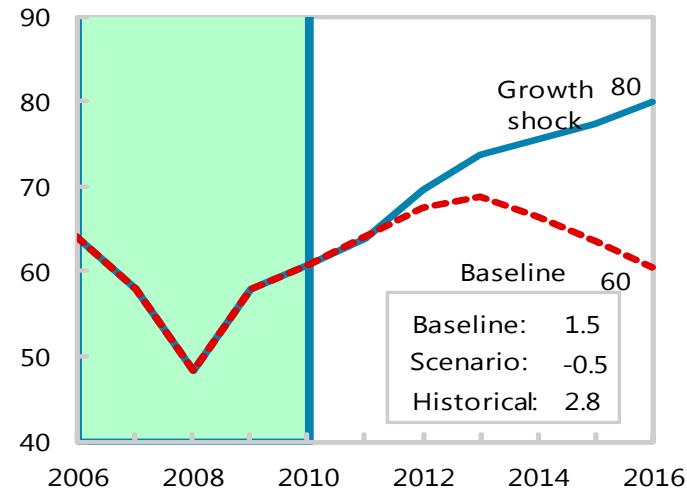

Primary balance shock (in percent of GDP) and no policy change scenario (constant primary balance

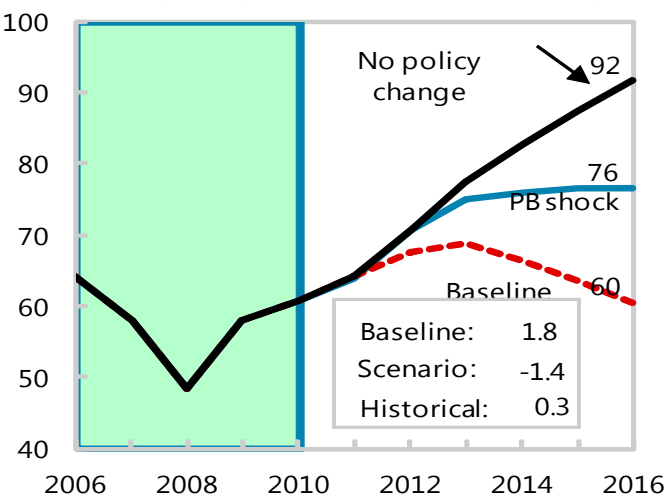

Combined shock 3/
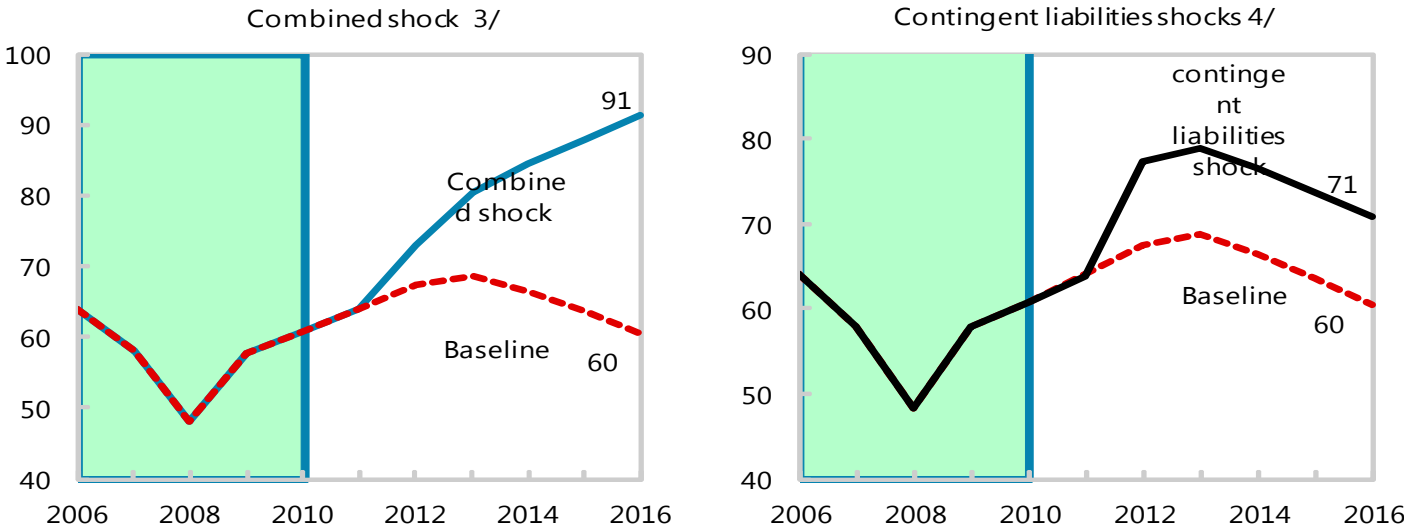

Sources: International Monetary Fund, country desk data, and staff estimates.

$1 /$ Shaded areas represent actual data. Individual shocks are permanent one standard deviation shocks.

Figures in the boxes represent average projections for the respective variables in the baseline and scenario being presented. Ten-year historical average for the variable is also shown.

2/ For historical scenarios, the historical averages are calculated overthe ten-year period, and the information

is used to project debt dynamics five years ahead. All individual shock scenarios assume a 1 standard deviation shock.

3/ Permanent 1 standard deviation shocks applied to real interest rate, growth rate, and primary balance. 4/10 percent of GDP shock to conting ent liabilities occur in 2011. 
Figure 6. Cyprus: External Sector

The current account deficit widened sharply in 2007 2008 but has since stabilized.

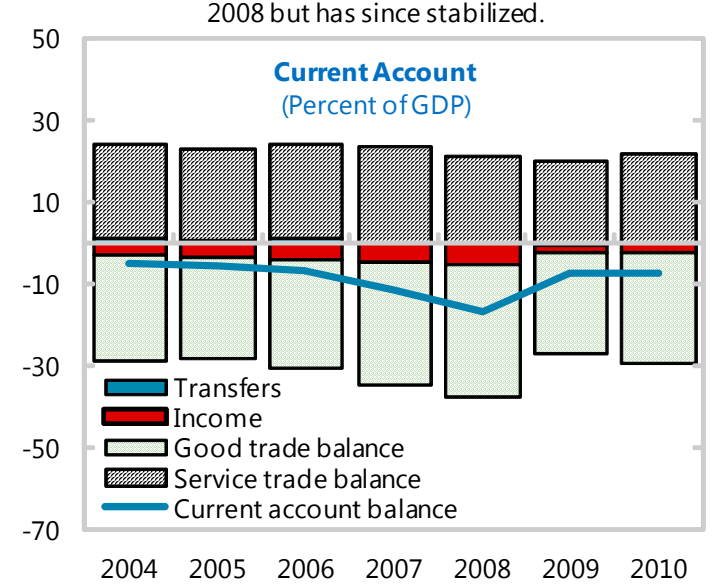

Increasing unit labor costs have been pricing out

$300 \quad$ Cypriot goods on international markets,...

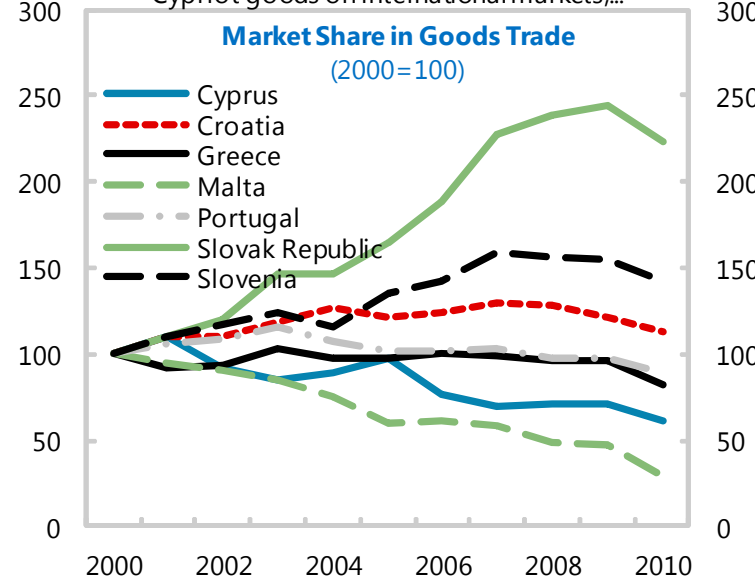

The deficit has been financed mostly by FDI except in 2008.

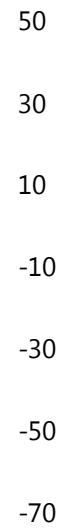

$-70$

$\begin{array}{cccc}-10 & & \text { Current account balance (rhs) } & \\ 2005 \mathrm{Q} 1 & 2007 \mathrm{Q} 1 & 2009 \mathrm{Q} 1 & 2011 \mathrm{Q} 1\end{array}$

...while service exports have grown, driven by business services and financial intermediation. 300 80

0 Oother current account financing

\section{Net FDI}

口Transport Services Exports (Percent of GDP)

$\square$ Travel

ther business services

- Financial and insurance services

$\square$ Governmentservices

$\square$ Other

40

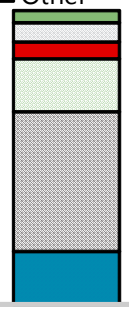

2000
80

70

60

50

40

30

20

10

0

Sources:IMF, Direction of Trade Statistics; Eurostat; and IMF, WEO. 
Figure 7. Cyprus: External Debt Sustainability: Bound Tests 1/2/ (External debt, percent of GDP)
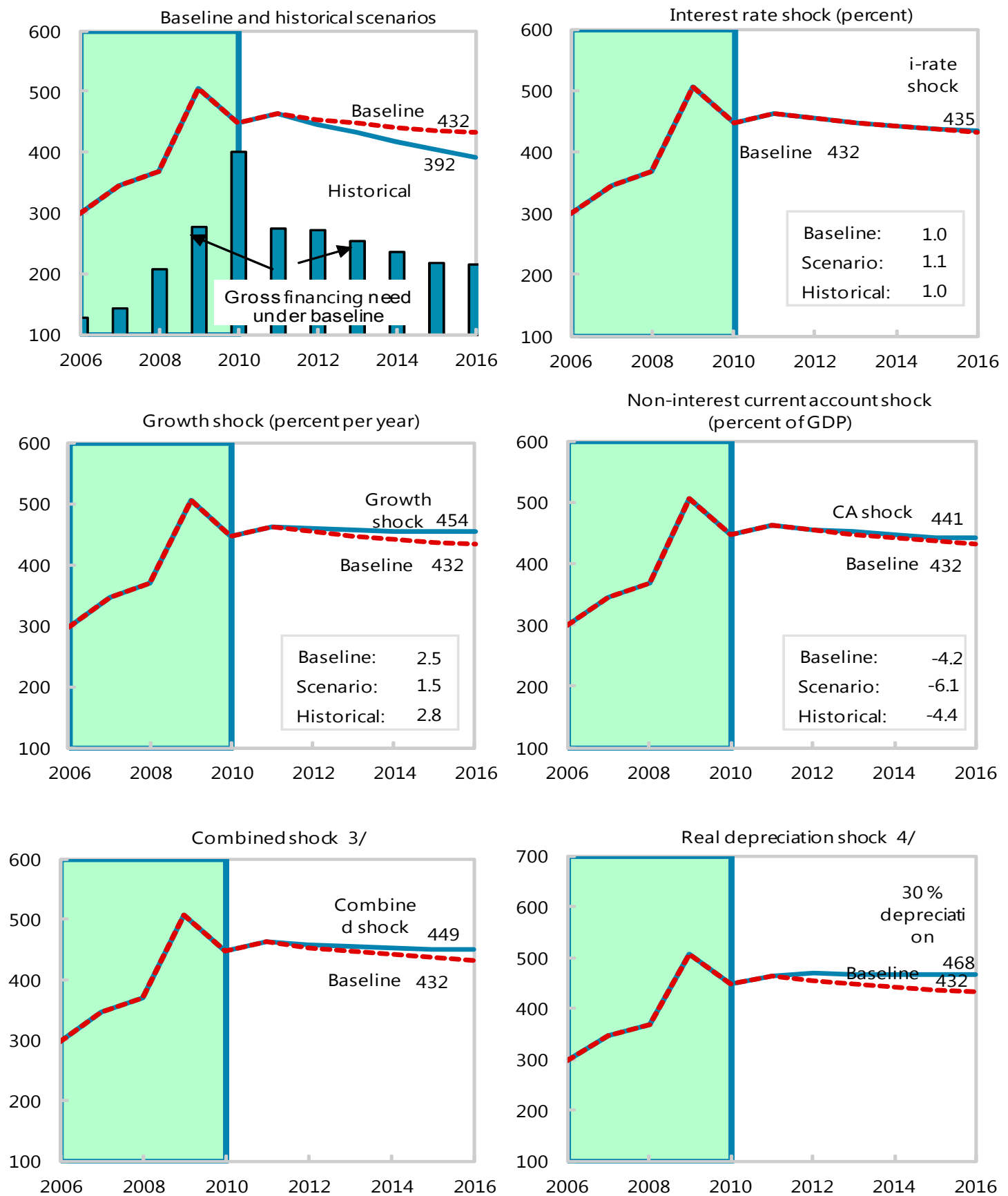

Sources: International Monetary Fund; Country desk data and IMF staff estimates.

$1 /$ Shaded areas represent actual data. Individual shocks are permanent one-half standard deviation shocks.

Figures in the boxes represent average projections for the respective variables in the baseline and scenario being presented. Ten-year historical average for the variable is also shown.

2/ For historical scenarios, the historical averages are calculated over the ten-year period, and the information is used to project debt dynamics five years ahead.

3/ Permanent $1 / 4$ standard deviation shocks applied to real interest rate, growth rate, and current account balance.

4/ One-time real depreciation of 30 percent occurs in 2011. 
Figure 8. Cyprus: Labor Market
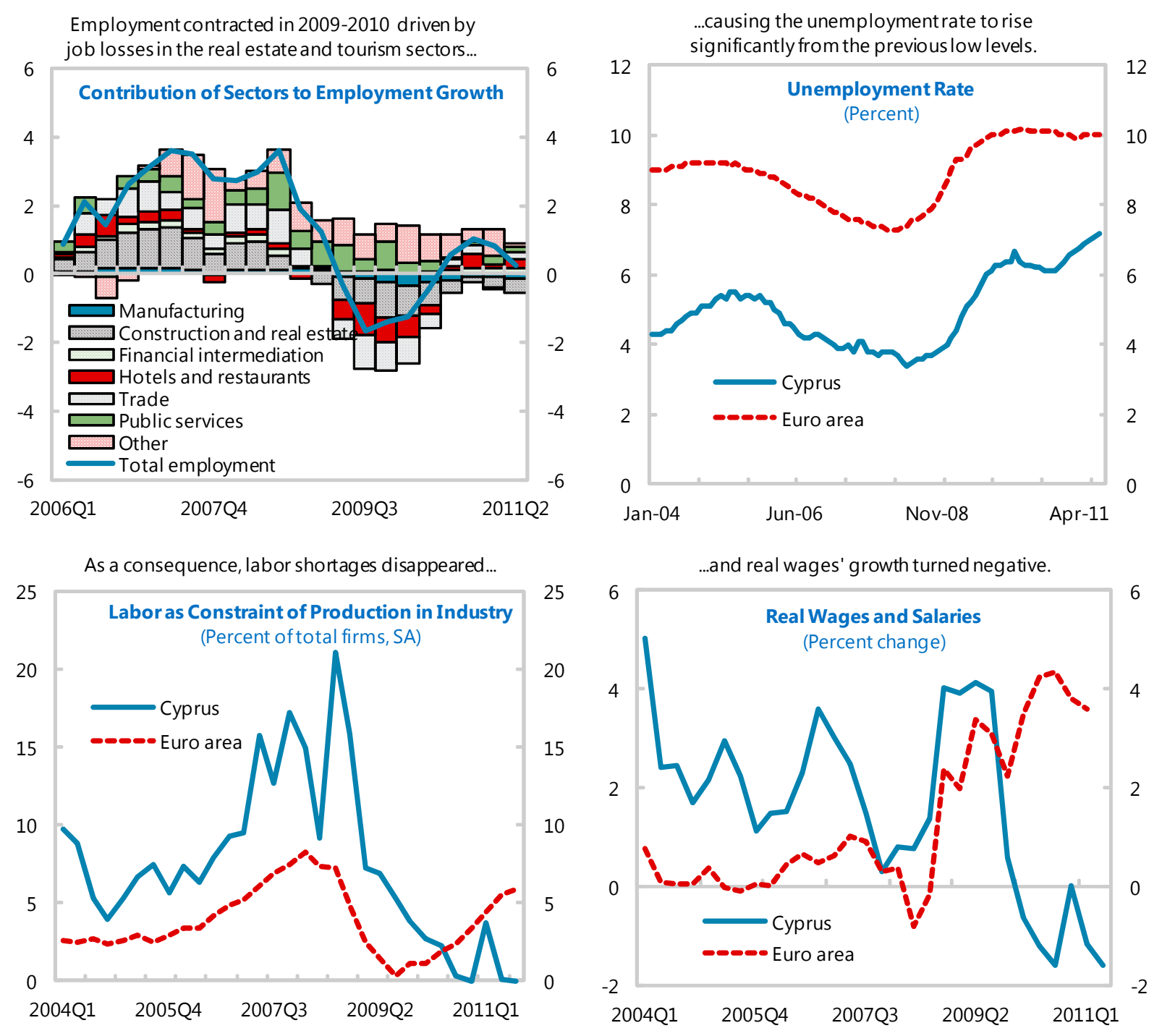


\begin{tabular}{|c|c|c|c|c|c|c|c|c|c|c|c|c|}
\hline & \multirow[t]{2}{*}{2005} & \multirow[t]{2}{*}{2006} & \multirow[t]{2}{*}{2007} & \multirow[t]{2}{*}{2008} & \multirow[t]{2}{*}{2009} & \multirow[t]{2}{*}{2010} & 2011 & 2012 & 2013 & 2014 & 2015 & 2016 \\
\hline & & & & & & & \multicolumn{6}{|c|}{ Proj. } \\
\hline Real Economy & \multicolumn{12}{|c|}{ (Percent change, unless otherwise indicated) } \\
\hline Real GDP & 3.9 & 4.1 & 5.1 & 3.6 & -1.9 & 1.1 & 0.0 & -1.0 & 0.8 & 2.0 & 2.8 & 3.0 \\
\hline Domestic demand & 3.3 & 5.7 & 8.8 & 7.9 & -6.9 & 1.0 & -0.3 & -3.6 & -1.0 & 1.7 & 2.5 & 2.9 \\
\hline Consumption & 3.4 & 5.2 & 7.8 & 7.4 & -4.8 & 2.0 & 0.8 & -2.2 & -0.7 & 0.4 & 2.1 & 2.7 \\
\hline Private consumption & 3.5 & 4.7 & 10.2 & 7.8 & -7.5 & 2.4 & 1.0 & -1.5 & 0.2 & 1.3 & 2.2 & 2.7 \\
\hline Public consumption & 3.4 & 7.0 & -0.8 & 5.6 & 6.2 & 0.6 & 0.1 & -4.8 & -4.5 & -3.4 & 1.8 & 2.7 \\
\hline Fixed investment & 4.1 & 10.2 & 13.4 & 6.0 & -9.7 & -6.9 & -5.9 & -5.0 & -5.0 & 4.5 & 5.0 & 5.2 \\
\hline Inventory accumulation $1 /$ & -0.2 & -0.4 & -0.1 & 0.9 & -1.4 & 0.7 & 0.0 & -1.0 & 0.5 & 0.6 & -0.1 & -0.2 \\
\hline Foreign balance $1 /$ & 0.5 & -1.9 & -4.4 & -5.4 & 6.5 & 0.1 & 1.0 & 2.8 & 1.8 & 0.3 & 0.3 & 0.0 \\
\hline Exports of goods and services & 4.9 & 3.6 & 6.2 & -0.1 & -11.0 & 6.1 & 3.2 & 2.2 & 3.0 & 3.9 & 4.2 & 4.4 \\
\hline Imports of goods and services & 3.7 & 6.8 & 13.4 & 8.6 & -18.7 & 5.1 & 1.0 & -3.0 & -0.5 & 3.3 & 3.5 & 4.2 \\
\hline Potential GDP growth & 3.7 & 3.6 & 3.2 & 2.4 & 1.7 & 1.5 & 1.3 & 1.0 & 1.0 & 1.3 & 1.5 & 2.0 \\
\hline Output gap (percent of potential GDP) & -0.8 & -0.3 & 1.6 & 2.8 & -0.8 & -1.2 & -2.4 & -4.3 & -4.5 & -3.8 & -2.6 & -1.6 \\
\hline HICP (period average) & 2.0 & 2.2 & 2.2 & 4.4 & 0.2 & 2.6 & 4.0 & 2.4 & 2.3 & 2.2 & 2.1 & 2.1 \\
\hline HICP (end of period) & 1.4 & 1.5 & 3.7 & 1.8 & 1.6 & 1.9 & 4.5 & 1.9 & 2.3 & 2.2 & 2.1 & 2.1 \\
\hline Unemployment rate EU stand. (percent) & 5.3 & 4.6 & 4.0 & 3.6 & 5.4 & 6.4 & 7.6 & 8.5 & 8.0 & 7.4 & 7.2 & 6.8 \\
\hline Employment growth (percent) & 2.5 & 2.7 & 5.8 & 1.3 & -0.4 & 1.0 & 0.3 & -0.2 & 1.0 & 1.5 & 2.0 & 2.0 \\
\hline Gross national savings (percent of GDP) & 14.2 & 14.0 & 10.6 & 7.2 & 12.5 & 11.3 & 10.9 & 11.5 & 11.2 & 12.1 & 12.2 & 12.4 \\
\hline Gross capital formation (percent of GDP) & 20.1 & 20.9 & 22.3 & 24.0 & 20.2 & 19.0 & 18.0 & 16.5 & 16.3 & 17.4 & 17.7 & 17.9 \\
\hline Public Finance & & & & & (Percen & of GDP) & & & & & & \\
\hline General government balance 2/ & -2.5 & -1.2 & 3.4 & 0.9 & -5.9 & -5.3 & -7.0 & -4.0 & -1.9 & 0.0 & 0.0 & 0.0 \\
\hline Revenue & 40.9 & 41.7 & 44.6 & 42.5 & 39.7 & 41.2 & 40.3 & 41.0 & 42.1 & 42.0 & 42.3 & 42.2 \\
\hline $\begin{array}{l}\text { Expenditure } \\
\text { General government debt }\end{array}$ & $\begin{array}{l}43.4 \\
68.8\end{array}$ & $\begin{array}{l}42.9 \\
64.1\end{array}$ & $\begin{array}{l}41.2 \\
58.0\end{array}$ & $\begin{array}{l}41.6 \\
48.2\end{array}$ & $\begin{array}{l}45.6 \\
57.8\end{array}$ & $\begin{array}{l}46.5 \\
60.7\end{array}$ & $\begin{array}{l}47.2 \\
64.0\end{array}$ & $\begin{array}{l}45.0 \\
67.5\end{array}$ & $\begin{array}{l}44.0 \\
68.7\end{array}$ & $\begin{array}{l}42.0 \\
66.3\end{array}$ & $\begin{array}{l}42.3 \\
63.5\end{array}$ & $\begin{array}{l}42.2 \\
60.4\end{array}$ \\
\hline Balance of Payments & & & & & (Percen & of GDP) & & & & & & \\
\hline Current account balance & -5.8 & -6.9 & -11.7 & -16.8 & -7.8 & -7.7 & -7.2 & -5.0 & -5.1 & -5.3 & -5.5 & -5.5 \\
\hline Trade Balance (goods and services) & -2.6 & -4.0 & -6.5 & -11.0 & -5.1 & -5.1 & -4.4 & -2.2 & -2.3 & -2.5 & -2.6 & -2.7 \\
\hline $\begin{array}{l}\text { Exports of goods and services } \\
\text { Imports of goods and services }\end{array}$ & $\begin{array}{l}47.3 \\
49.9\end{array}$ & $\begin{array}{l}46.7 \\
50.7\end{array}$ & $\begin{array}{l}46.9 \\
53.4\end{array}$ & $\begin{array}{l}44.6 \\
55.6\end{array}$ & $\begin{array}{l}39.5 \\
44.6\end{array}$ & $\begin{array}{l}42.1 \\
47.2\end{array}$ & $\begin{array}{l}43.2 \\
47.6\end{array}$ & $\begin{array}{l}44.7 \\
46.8\end{array}$ & $\begin{array}{l}44.6 \\
46.9\end{array}$ & $\begin{array}{l}44.7 \\
47.2\end{array}$ & $\begin{array}{l}45.4 \\
48.1\end{array}$ & $\begin{array}{l}45.8 \\
48.4\end{array}$ \\
\hline Goods balance & -24.9 & -27.0 & -29.5 & -31.9 & -24.9 & -26.8 & -24.3 & -23.5 & -23.9 & -24.5 & -24.9 & -25.0 \\
\hline Services balance & 22.3 & 23.0 & 23.0 & 20.9 & 19.8 & 21.7 & 19.9 & 21.3 & 21.6 & 22.0 & 22.3 & 22.4 \\
\hline Income, net & -3.7 & -4.0 & -5.1 & -5.6 & -1.6 & -2.7 & -2.7 & -2.7 & -2.7 & -2.7 & -2.7 & -2.7 \\
\hline Transfers, net & 0.5 & 1.1 & 0.0 & -0.2 & -1.1 & 0.0 & -0.1 & -0.1 & -0.1 & -0.1 & -0.1 & -0.1 \\
\hline Capital account, net & 0.5 & 0.2 & 0.0 & 0.0 & 0.4 & 0.2 & 0.1 & 0.1 & 0.1 & 0.1 & 0.1 & 0.1 \\
\hline Financial account, net & 4.3 & 6.8 & 11.9 & 16.4 & 8.0 & 8.0 & 7.1 & 4.9 & 5.0 & 5.3 & 5.4 & 5.4 \\
\hline Direct investment & 3.7 & 5.2 & 4.5 & -1.3 & 5.9 & 4.4 & 4.3 & 4.3 & 4.4 & 4.4 & 4.3 & 4.3 \\
\hline Portfolio investment & -0.8 & -0.9 & -2.0 & -72.1 & -67.0 & -8.2 & 1.0 & -0.2 & -0.5 & -2.0 & -2.5 & -3.0 \\
\hline Other investment & 5.6 & 7.9 & 8.0 & 88.2 & 68.6 & 10.7 & 1.8 & 0.8 & 1.1 & 2.9 & 3.6 & 4.1 \\
\hline Reserves ( - inflow; + outflow) & -4.2 & -5.4 & 1.4 & 1.7 & 0.5 & 1.1 & 0.0 & 0.0 & 0.0 & 0.0 & 0.0 & 0.0 \\
\hline Errors and omissions & 1.0 & -0.1 & -0.3 & 0.4 & -0.6 & -0.4 & 0.0 & 0.0 & 0.0 & 0.0 & 0.0 & 0.0 \\
\hline \multicolumn{13}{|l|}{ Savings-Investment Balance } \\
\hline National saving & 14.2 & 14.0 & 10.6 & 7.2 & 12.5 & 11.3 & 10.9 & 11.5 & 11.2 & 12.1 & 12.2 & 12.4 \\
\hline Government & 1.2 & 2.6 & 7.3 & 4.7 & -0.6 & -0.2 & -1.9 & 1.2 & 3.3 & 5.0 & 5.2 & 5.3 \\
\hline Non-government & 13.1 & 11.3 & 3.3 & 2.4 & 13.0 & 11.5 & 12.8 & 10.3 & 7.9 & 7.1 & 7.1 & 7.1 \\
\hline Gross capital formation & 20.1 & 20.9 & 22.3 & 24.0 & 20.2 & 19.0 & 18.0 & 16.5 & 16.3 & 17.4 & 17.7 & 17.9 \\
\hline Government & 3.6 & 3.8 & 3.9 & 3.8 & 5.4 & 5.1 & 5.1 & 5.2 & 5.2 & 5.0 & 5.2 & 5.3 \\
\hline Non-government & 16.4 & 17.0 & 18.4 & 20.1 & 14.8 & 14.0 & 13.0 & 11.2 & 11.0 & 12.4 & 12.5 & 12.6 \\
\hline Foreign saving & -5.8 & -6.9 & -11.7 & -16.8 & -7.8 & -7.7 & -7.2 & -5.0 & -5.1 & -5.3 & -5.5 & -5.5 \\
\hline \multicolumn{13}{|l|}{ Memorandum Item: } \\
\hline Nominal GDP (billions of euros) & 13.5 & 14.6 & 16.0 & 17.3 & 17.0 & 17.5 & 18.2 & 18.4 & 18.6 & 19.3 & 20.1 & 21.2 \\
\hline
\end{tabular}


Table 2. Cyprus: Fiscal Developments and Projections, 2005-2016 (Percent of GDP)

\begin{tabular}{|c|c|c|c|c|c|c|c|c|c|c|c|c|}
\hline & 2005 & 2006 & 2007 & 2008 & 2009 & 2010 & 2011 & 2012 & 2013 & 2014 & 2015 & 2016 \\
\hline & & & & & & & \multicolumn{6}{|c|}{ Proj. } \\
\hline Revenue & 40.9 & 41.7 & 44.6 & 42.5 & 39.7 & 41.2 & 40.3 & 41.0 & 42.1 & 42.0 & 42.3 & 42.2 \\
\hline Current revenue & 40.9 & 41.6 & 44.5 & 42.5 & 39.5 & 41.2 & 40.2 & 40.9 & 42.1 & 42.0 & 42.2 & 42.2 \\
\hline Tax revenue & 26.7 & 27.9 & 32.2 & 30.3 & 26.2 & 26.3 & 25.9 & 26.5 & 27.2 & 27.2 & 27.3 & 27.3 \\
\hline Indirect taxes & 16.4 & 17.1 & 18.4 & 17.5 & 15.0 & 15.3 & 15.2 & 15.5 & 16.1 & 16.1 & 16.2 & 16.2 \\
\hline Direct taxes & 9.3 & 10.9 & 13.7 & 12.8 & 11.1 & 11.0 & 10.7 & 11.0 & 11.1 & 11.1 & 11.1 & 11.1 \\
\hline Other taxes (capital taxes) & 0.9 & 0.0 & 0.0 & 0.0 & 0.0 & 0.0 & 0.0 & 0.0 & 0.0 & 0.0 & 0.0 & 0.0 \\
\hline Social security contributions & 8.3 & 7.9 & 7.5 & 7.7 & 8.6 & 9.6 & 9.8 & 10.1 & 10.1 & 10.0 & 10.0 & 10.0 \\
\hline Other current revenue & 5.9 & 5.8 & 4.8 & 4.5 & 4.7 & 5.3 & 4.5 & 4.4 & 4.8 & 4.8 & 4.9 & 4.9 \\
\hline Capital revenue & 0.1 & 0.1 & 0.1 & 0.0 & 0.1 & 0.0 & 0.0 & 0.0 & 0.0 & 0.0 & 0.0 & 0.0 \\
\hline Expenditure & 43.4 & 42.9 & 41.2 & 41.6 & 45.6 & 46.5 & 47.2 & 45.0 & 44.0 & 42.0 & 42.3 & 42.2 \\
\hline Current expenditure & 39.8 & 39.1 & 37.3 & 37.8 & 40.2 & 41.5 & 42.2 & 39.8 & 38.8 & 37.1 & 37.1 & 36.9 \\
\hline Wages and salaries & 15.0 & 15.0 & 14.3 & 14.2 & 15.7 & 15.4 & 15.4 & 14.8 & 14.1 & 13.4 & 13.4 & 13.4 \\
\hline Goods and services & 4.9 & 5.3 & 4.5 & 4.7 & 4.9 & 5.2 & 5.1 & 5.1 & 5.0 & 4.8 & 4.8 & 4.8 \\
\hline Social Transfers & 13.0 & 12.5 & 11.6 & 12.1 & 13.4 & 14.8 & 14.9 & 13.7 & 13.2 & 12.7 & 12.8 & 12.8 \\
\hline Subsidies & 0.7 & 0.5 & 0.4 & 0.4 & 0.2 & 0.2 & 0.4 & 0.3 & 0.3 & 0.2 & 0.2 & 0.2 \\
\hline Interest payments & 3.6 & 3.3 & 3.0 & 2.8 & 2.5 & 2.2 & 2.5 & 2.8 & 3.0 & 3.1 & 3.0 & 2.9 \\
\hline Other current expenditure & 2.6 & 2.4 & 3.4 & 3.7 & 3.5 & 3.7 & 3.9 & 3.2 & 3.1 & 2.9 & 2.9 & 2.9 \\
\hline Capital expenditure & 3.6 & 3.8 & 3.9 & 3.8 & 5.4 & 5.1 & 5.1 & 5.2 & 5.2 & 5.0 & 5.2 & 5.3 \\
\hline Overall balance $1 /$ & -2.5 & -1.2 & 3.4 & 0.9 & -5.9 & -5.3 & -7.0 & -4.0 & -1.9 & 0.0 & 0.0 & 0.0 \\
\hline Overall balance excl. one-offs & -3.4 & -3.2 & -1.1 & -1.1 & -6.2 & -5.8 & -7.1 & -4.1 & -1.9 & 0.0 & 0.0 & 0.0 \\
\hline Statistical discrepancy & -0.1 & 0.0 & 0.0 & 0.0 & 0.0 & 0.0 & 0.0 & 0.0 & 0.0 & 0.0 & 0.0 & 0.0 \\
\hline Financing & -2.4 & -1.2 & 3.4 & 0.9 & -5.9 & -5.3 & -7.0 & -4.0 & -1.9 & 0.0 & 0.0 & 0.0 \\
\hline Net financial transactions & -2.4 & -1.2 & 3.4 & 0.9 & -5.9 & -5.3 & -7.0 & -4.0 & -1.9 & 0.0 & 0.0 & 0.0 \\
\hline Net acquisition of financial assets & 0.8 & -0.8 & 2.9 & -4.3 & 2.8 & -0.7 & -1.2 & 0.0 & 0.0 & 0.0 & 0.0 & 0.0 \\
\hline Currency and deposits & 0.3 & -0.3 & 2.4 & -4.4 & 2.0 & -1.4 & -1.2 & 0.0 & 0.0 & 0.0 & 0.0 & 0.0 \\
\hline Securities other than shares & 0.0 & 0.0 & 0.0 & 0.0 & 0.0 & 0.0 & 0.0 & 0.0 & 0.0 & 0.0 & 0.0 & 0.0 \\
\hline Loans & 0.2 & -0.6 & 0.1 & 0.2 & 0.5 & 0.7 & 0.0 & 0.0 & 0.0 & 0.0 & 0.0 & 0.0 \\
\hline Shares and other equity & 0.0 & 0.0 & 0.2 & -0.3 & 0.0 & 0.0 & 0.0 & 0.0 & 0.0 & 0.0 & 0.0 & 0.0 \\
\hline Other financial assets & 0.3 & 0.1 & 0.3 & 0.2 & 0.3 & 0.0 & 0.0 & 0.0 & 0.0 & 0.0 & 0.0 & 0.0 \\
\hline Net incurrence of liabilities & 3.2 & 0.4 & -0.4 & -5.2 & 8.8 & 4.6 & 5.8 & 4.0 & 1.9 & 0.0 & 0.0 & 0.0 \\
\hline Currency and deposits & 0.0 & 0.0 & 0.0 & 0.0 & 0.0 & 0.0 & 0.0 & 0.0 & 0.0 & 0.0 & 0.0 & 0.0 \\
\hline Securities other than shares & 2.4 & 0.2 & -1.0 & -8.3 & 9.1 & 4.7 & 5.8 & -6.6 & -12.8 & 0.0 & 0.0 & 0.0 \\
\hline Loans & 0.6 & 0.1 & 0.5 & 3.0 & -0.3 & -0.1 & 0.0 & 10.7 & 14.7 & 0.0 & 0.0 & 0.0 \\
\hline Other liabilities & 0.2 & 0.0 & 0.0 & 0.1 & 0.0 & 0.0 & 0.0 & 0.0 & 0.0 & 0.0 & 0.0 & 0.0 \\
\hline
\end{tabular}

Memorandum items:

Financing need to be covered with non market/unidentified financing $1 /$ Cyclically adjusted overall balance Cyclically adjusted overall balance, excl. one-offs

Cyclical balance

Cyclically adjusted primary

balance, excl. one-offs

Primary balance

One-offs

$\begin{array}{rrrrrrrrrrrr}\ldots & \ldots & \ldots & \ldots & \ldots & \ldots & \ldots & 10.7 & 14.7 & \ldots & \ldots & \ldots \\ -2.2 & -1.1 & 2.7 & -0.2 & -5.6 & -4.8 & -6.0 & -2.4 & -0.2 & 1.5 & 1.0 & 0.6 \\ & & & & & & & & & & & \\ -3.1 & -3.1 & -1.8 & -2.2 & -5.9 & -5.3 & -6.1 & -2.5 & -0.2 & 1.5 & 1.0 & 0.6 \\ -0.3 & -0.1 & 0.6 & 1.1 & -0.3 & -0.5 & -0.9 & -1.7 & -1.8 & -1.5 & -1.0 & -0.6 \\ & & & & & & & & & & & \\ 0.5 & 0.2 & 1.3 & 0.6 & -3.4 & -3.1 & -3.6 & 0.3 & 2.9 & 4.6 & 4.0 & 3.6 \\ 1.1 & 2.1 & 6.4 & 3.7 & -3.4 & -3.1 & -4.4 & -1.2 & 1.1 & 3.1 & 3.0 & 2.9 \\ 0.9 & 2.0 & 4.5 & 2.0 & 0.3 & 0.5 & 0.1 & 0.1 & 0.0 & 0.0 & 0.0 & 0.0 \\ 68.8 & 64.1 & 58.0 & 48.2 & 57.8 & 60.7 & 64.0 & 67.5 & 68.7 & 66.3 & 63.5 & 60.4\end{array}$

Sources: Eurostat, and IMF staff estimates.

1/ Fiscal financing needs assuming no rollover of long term debt in 2012-2013. This does not include any fiscal outlays for recapitalizing banks. 
Table 3. Cyprus: Public Sector Debt Sustainability Framework, 2006-2016 (Percent of GDP, unless otherwise indicated)

\begin{tabular}{|c|c|c|c|c|c|c|c|c|c|c|c|c|}
\hline & \multirow[b]{2}{*}{2006} & \multicolumn{3}{|c|}{ Actual } & \multirow[b]{2}{*}{2010} & \multirow[b]{2}{*}{2011} & \multicolumn{4}{|c|}{ Projections } & \multirow[b]{2}{*}{2016} & \multirow[b]{3}{*}{$\begin{array}{c}\text { Debt- } \\
\text { stabilizing } \\
\text { primary } \\
\text { balance 9/ }\end{array}$} \\
\hline & & 2007 & 2008 & 2009 & & & 2012 & 2013 & 2014 & 2015 & & \\
\hline & & & & & & & & & & & & \\
\hline Baseline: Public sector debt $\mathbf{1}$ / & 64.1 & 58.0 & 48.2 & 57.8 & 60.7 & 64.0 & 67.5 & 68.7 & 66.3 & 63.5 & 60.4 & -0.1 \\
\hline Of which: foreign-currency denominated & 0.0 & 0.0 & 0.0 & 0.0 & 0.0 & 0.0 & 0.0 & 0.0 & 0.0 & 0.0 & 0.0 & $\ldots$ \\
\hline Change in public sector debt & -4.7 & -6.1 & -9.8 & 9.6 & 2.9 & 3.3 & 3.5 & 1.2 & -2.3 & -2.8 & -3.1 & $\ldots$ \\
\hline Identified debt-creating flows $(4+7+12)$ & -3.4 & -9.2 & -5.6 & 7.0 & 3.5 & 4.2 & 3.5 & 1.2 & -2.3 & -2.8 & -3.1 & $\ldots$ \\
\hline Primary deficit & -2.1 & -6.4 & -3.7 & 3.4 & 3.1 & 4.4 & 1.2 & -1.1 & -3.1 & -3.0 & -2.9 & $\ldots$ \\
\hline Revenue and grants & 41.7 & 44.6 & 42.5 & 39.7 & 41.2 & 40.3 & 41.0 & 42.1 & 42.0 & 42.3 & 42.2 & $\ldots$ \\
\hline Primary (noninterest) expenditure & 39.6 & 38.2 & 38.8 & 43.1 & 44.3 & 44.7 & 42.2 & 41.0 & 39.0 & 39.3 & 39.3 & $\ldots$ \\
\hline Automatic debt dynamics $2 /$ & -1.3 & -2.8 & -1.9 & 3.6 & 0.4 & -0.2 & 2.3 & 2.3 & 0.7 & 0.2 & -0.1 & $\ldots$ \\
\hline Contribution from interest rate/growth differential 3/ & -1.3 & -2.8 & -1.9 & 3.6 & 0.4 & -0.2 & 2.3 & 2.3 & 0.7 & 0.2 & -0.1 & $\ldots$ \\
\hline Of which contribution from real interest rate & 1.3 & 0.2 & 0.0 & 2.7 & 1.1 & -0.2 & 1.6 & 2.8 & 2.1 & 1.9 & 1.7 & $\ldots$ \\
\hline Of which contribution from real GDP growth & -2.6 & -3.0 & -1.9 & 0.9 & -0.6 & 0.0 & 0.6 & -0.5 & -1.3 & -1.8 & -1.8 & $\ldots$ \\
\hline Contribution from exchange rate depreciation 4/ & 0.0 & 0.0 & 0.0 & 0.0 & 0.0 & $\ldots$ & $\ldots$ & $\ldots$ & $\ldots$ & $\ldots$ & $\ldots$ & $\ldots$ \\
\hline Other identified debt-creating flows & 0.0 & 0.0 & 0.0 & 0.0 & 0.0 & 0.0 & 0.0 & 0.0 & 0.0 & 0.0 & 0.0 & $\ldots$ \\
\hline Privatization receipts (negative) & 0.0 & 0.0 & 0.0 & 0.0 & 0.0 & 0.0 & 0.0 & 0.0 & 0.0 & 0.0 & 0.0 & $\ldots$ \\
\hline Recognition of implicit or contingent liabilities & 0.0 & 0.0 & 0.0 & 0.0 & 0.0 & 0.0 & 0.0 & 0.0 & 0.0 & 0.0 & 0.0 & $\ldots$ \\
\hline Other (specify, e.g. bank recapitalization) & 0.0 & 0.0 & 0.0 & 0.0 & 0.0 & 0.0 & 0.0 & 0.0 & 0.0 & 0.0 & 0.0 & $\ldots$ \\
\hline Residual, including asset changes (2-3) 5/ & -1.3 & 3.1 & -4.1 & 2.5 & -0.6 & -0.9 & 0.0 & 0.0 & 0.0 & 0.0 & 0.0 & $\ldots$ \\
\hline Public sector debt-to-revenue ratio $1 /$ & 153.7 & 130.2 & 113.3 & 145.7 & 147.2 & 158.9 & 164.7 & 163.1 & 157.8 & 150.2 & 143.2 & $\ldots$ \\
\hline Gross financing need 6/ & 11.6 & 5.6 & 4.8 & 14.0 & 18.8 & 13.3 & 17.4 & 21.3 & 11.8 & 15.6 & 14.8 & $\ldots$ \\
\hline Billions of U.S. dollars & 1.3 & 0.7 & 0.6 & 1.7 & 2.5 & 1.7 & 2.3 & 2.8 & 1.6 & 2.3 & 2.3 & $\ldots$ \\
\hline \multicolumn{13}{|l|}{ Scenario with key variables at their historical } \\
\hline averages $7 /$ & $\ldots$ & $\ldots$ & $\ldots$ & $\ldots$ & $\ldots$ & 64.0 & 63.4 & 62.8 & 62.2 & 61.5 & 60.9 & -0.3 \\
\hline \multicolumn{13}{|l|}{ Scenario with no policy change (constant primary } \\
\hline balance) in 2011-2016 & $\cdots$ & $\cdots$ & $\cdots$ & $\cdots$ & $\ldots$ & 64.0 & 70.7 & 77.5 & 82.7 & 87.4 & 91.6 & -0.2 \\
\hline \multicolumn{13}{|c|}{ Key Macroeconomic and Fiscal Assumptions Underlying Baseline } \\
\hline Real GDP growth (percent) & 4.1 & 5.1 & 3.6 & -1.9 & 1.1 & 0.0 & -1.0 & 0.8 & 2.0 & 2.8 & 3.0 & $\ldots$ \\
\hline $\begin{array}{l}\text { Average nominal interest rate on public debt (percent) 8/ } \\
\text { Average real interest rate (nominal rate minus change in }\end{array}$ & 5.1 & 5.2 & 5.2 & 5.2 & 3.9 & 4.4 & 4.4 & 4.5 & 4.6 & 4.7 & 4.8 & $\ldots$ \\
\hline GDP deflator, percent) & 2.2 & 0.5 & 0.2 & 5.5 & 1.9 & -0.4 & 2.6 & 4.2 & 3.2 & 3.1 & 2.8 & $\ldots$ \\
\hline \multicolumn{13}{|l|}{ Nominal appreciation (increase in US dollar value of } \\
\hline local currency, percent) & -9.5 & -8.1 & 6.8 & -6.7 & 10.4 & $\ldots$ & $\ldots$ & $\ldots$ & $\ldots$ & $\ldots$ & $\ldots$ & $\ldots$ \\
\hline Inflation rate (GDP deflator, percent) & 3.0 & 4.6 & 5.1 & -0.3 & 2.0 & 4.7 & 1.9 & 0.3 & 1.5 & 1.6 & 2.0 & $\ldots$ \\
\hline \multicolumn{13}{|l|}{ Growth of real primary spending (deflated by GDP } \\
\hline deflator, percent) & 3.9 & 1.0 & 5.0 & 9.3 & 3.8 & 0.5 & -6.5 & -2.0 & -3.1 & 3.6 & 3.1 & $\ldots$ \\
\hline Primary deficit & -2.1 & -6.4 & -3.7 & 3.4 & 3.1 & 4.4 & 1.2 & -1.1 & -3.1 & -3.0 & -2.9 & $\ldots$ \\
\hline
\end{tabular}

$1 /$ Indicate coverage of public sector, e.g., general government or nonfinancial public sector. Also whether net or gross debt is used.

2/ Derived as $[(r-p(1+g)-g+a e(1+r)] /(1+g+p+g p))$ times previous period debt ratio, with $r=$ interest rate; $p=$ growth rate of GDP deflator; $g=$ real GDP growth rate; $a=$ share of foreign-currency denominated debt; and $\mathrm{e}=$ nominal exchange rate depreciation (measured by increase in local currency value of U.S. dollar).

3 / The real interest rate contribution is derived from the denominator in footnote $2 /$ as $r-\pi(1+g)$ and the real growth contribution as $-g$.

4/ The exchange rate contribution is derived from the numerator in footnote $2 /$ as ae( $1+r)$.

5 / For projections, this line includes exchange rate changes.

6/ Defined as public sector deficit, plus amortization of medium and long-term public sector debt, plus short-term debt at end of previous period.

7/ The key variables include real GDP growth; real interest rate; and primary balance in percent of GDP.

8/ Derived as nominal interest expenditure divided by previous period debt stock.

9/ Assumes that key variables (real GDP growth, real interest rate, and other identified debt-creating flows) remain at the level of the last projection year. 


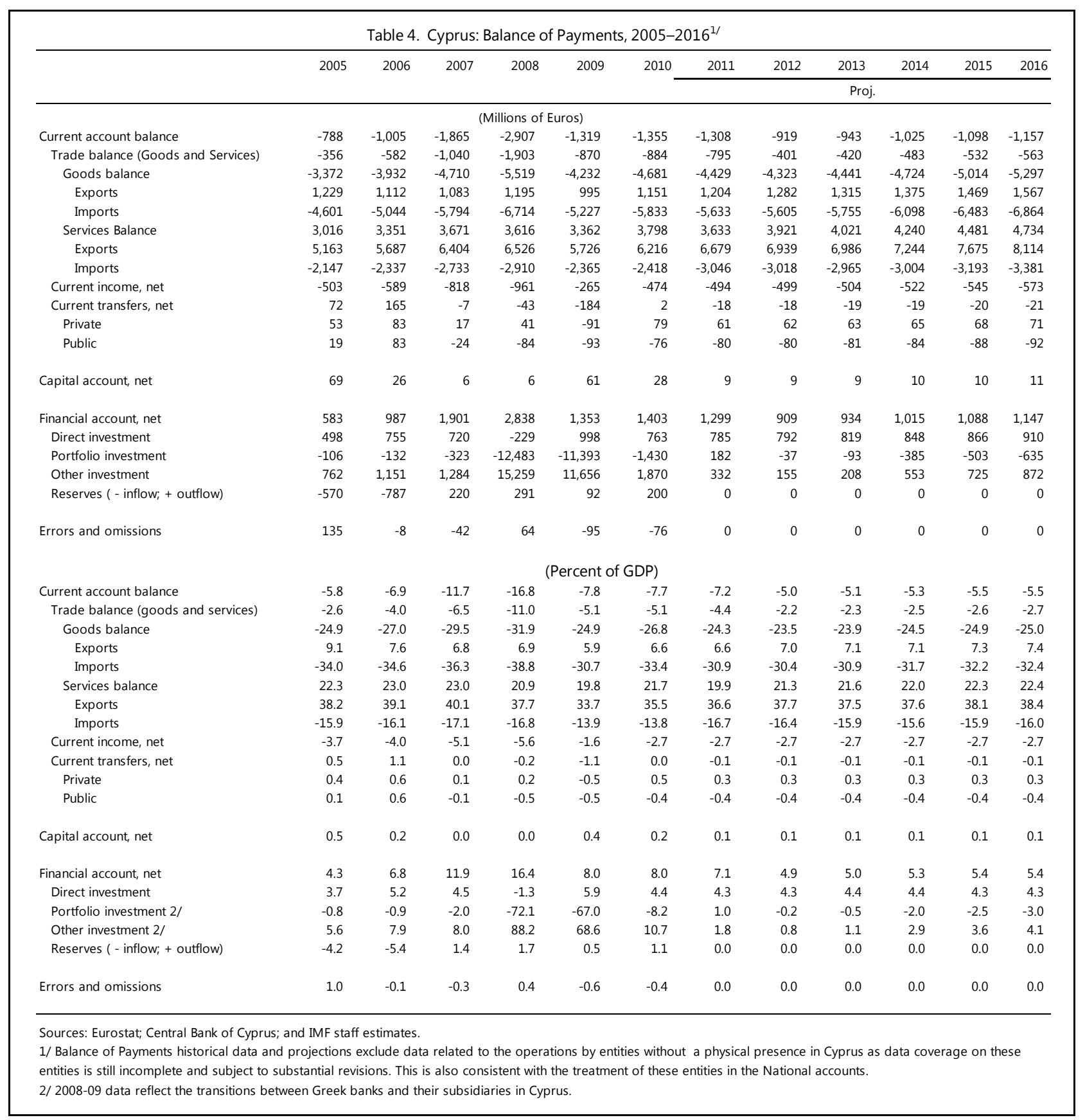




\begin{tabular}{|c|c|c|c|c|c|c|c|c|c|c|c|c|c|c|}
\hline \multicolumn{15}{|c|}{$\begin{array}{l}\text { Table 5. Cyprus: External Debt Sustainability Framework, 2006-2016 } \\
\text { (Percent of GDP, unless otherwise indicated) }\end{array}$} \\
\hline & \multicolumn{5}{|c|}{ Actual } & & & \multicolumn{7}{|c|}{ Projections } \\
\hline & 2006 & 2007 & 2008 & 2009 & 2010 & & & 2011 & 2012 & 2013 & 2014 & 2015 & 2016 & Debt-stabilizing \\
\hline Baseline: External debt & 297.7 & 346.1 & 368.6 & 505.9 & 446.9 & & & 462.4 & 453.4 & 447.2 & 441.3 & 435.5 & 432.4 & -17.4 \\
\hline Change in external debt & 57.1 & 48.3 & 22.6 & 137.3 & -59.0 & & & 15.5 & -9.0 & -6.2 & -5.9 & -5.8 & -3.1 & $\ldots$ \\
\hline Identified external debt-creating flows $(4+8+9)$ & -15.8 & -36.2 & 37.4 & 80.4 & -3.2 & & & -3.6 & -5.1 & -5.6 & -5.0 & -5.2 & -4.4 & $\ldots$ \\
\hline Current account deficit, excluding interest payments & 4.0 & 9.0 & 13.6 & 2.8 & 2.5 & & & 4.6 & 4.4 & 4.3 & 4.3 & 4.0 & 4.0 & $\ldots$ \\
\hline Deficit in balance of goods and services & 4.0 & 6.5 & 7.4 & 0.0 & 1.3 & & & 3.9 & 3.7 & 3.4 & 3.4 & 3.0 & 3.0 & $\ldots$ \\
\hline Exports & 47.1 & 47.2 & 55.7 & 51.1 & 50.9 & & & 52.0 & 52.6 & 53.2 & 53.7 & 54.1 & 54.8 & $\ldots . .$. \\
\hline Imports & 51.1 & 53.7 & 63.1 & 51.1 & 52.2 & & & 55.9 & 56.2 & 56.6 & 57.0 & 57.2 & 57.8 & $\ldots$ \\
\hline Net non-debt creating capital inflows (negative) & -4.3 & -2.4 & 68.2 & 64.6 & 3.8 & & & -5.5 & -4.1 & -3.7 & -2.3 & -1.7 & -1.2 & $\ldots$ \\
\hline Automatic debt dynamics $1 /$ & -15.6 & -42.8 & -44.4 & 13.0 & -9.5 & & & -2.8 & -5.5 & -6.2 & -7.0 & -7.5 & -7.1 & $\ldots$ \\
\hline Contribution from nominal interest rate & 3.0 & 2.7 & 3.6 & 4.8 & 4.5 & & & 4.2 & 4.2 & 4.2 & 4.1 & 4.0 & 4.0 & ... \\
\hline Contribution from real GDP growth & -9.2 & -12.9 & -10.8 & 6.6 & -5.4 & & & -7.0 & -9.7 & -10.3 & -11.1 & -11.6 & -11.1 & ... \\
\hline Contribution from price and exchange rate changes $2 /$ & -9.4 & -32.7 & -37.2 & 1.6 & -8.7 & & & $\ldots$ & ... &... & $\ldots$ & & $\ldots$ & $\ldots$ \\
\hline Residual, incl. change in gross foreign assets (2-3) 3/ & 72.9 & 84.5 & -14.8 & 56.9 & -55.7 & & & 19.1 & -3.9 & -0.5 & -0.9 & -0.5 & 1.2 & $\ldots$ \\
\hline External debt-to-exports ratio (in percent) & 632.2 & 733.9 & 662.2 & 990.6 & 878.5 & & & 889.3 & 862.3 & 841.2 & 822.1 & 804.4 & 788.7 & ... \\
\hline Gross external financing need (in billions of US dollars) $4 /$ & 23.5 & 31.0 & 52.6 & 65.2 .250 .50 & 92.9 & & & 68.5 & 71.0 & 69.1 & 67.3 & 64.7 & 66.8 & $\ldots$ \\
\hline in percent of GDP & 127.4 & 142.2 & 206.6 & 276.2 & 401.0 & 10-Year & 10-Year & 273.6 & 271.4 & 253.2 & 236.5 & 217.3 & 215.5 & ... \\
\hline Scenario with key variables at their historical averages 5/ & & & & & & & & 462.4 & 446.6 & 432.3 & 417.7 & 404.5 & 392.2 & -23.8 \\
\hline & & & & & & Historical & Standard & & & & & & & \\
\hline Key Macroeconomic Assumptions Underlying Baseline & & & & & & Average & Deviation & & & & & & & \\
\hline Real GDP growth (in percent) & 4.1 & 5.1 & 3.6 & 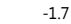 & 1.0 & 2.8 & 2.0 & 1.7 & 2.2 & 2.4 & 2.6 & 2.7 & 2.7 & $\ldots .$. \\
\hline GDP deflator in US dollars (change in percent) & 4.1 & 12.7 & 12.4 & -5.7 & -2.8 & 6.9 & 9.0 & 6.2 & 2.4 & 1.8 & 1.7 & 1.8 & 1.4 & $\ldots$ \\
\hline Nominal external interest rate (in percent) & 1.3 & 1.1 & 1.2 & 1.2 & 0.9 & 1.0 & 0.2 & 1.0 & 1.0 & 1.0 & 1.0 & 1.0 & 1.0 & $\ldots$ \\
\hline Growth of exports (US dollar terms, in percent) & 5.9 & 18.7 & 37.5 & -14.9 & -2.2 & 9.7 & 14.2 & 10.4 & 5.8 & 5.4 & 5.3 & 5.4 & 5.4 & $\ldots$ \\
\hline Growth of imports (US dollar terms, in percent) & 8.9 & 24.5 & 36.8 & -24.9 & 0.3 & 10.2 & 16.9 & 15.5 & 5.3 & 4.9 & 5.1 & 4.8 & 5.3 & $\ldots$ \\
\hline Current account balance, excluding interest payments & -4.0 & -9.0 & -13.6 & -2.8 & -2.5 & -4.4 & 3.9 & -4.6 & -4.4 & -4.3 & -4.3 & -4.0 & -4.0 & $\ldots$ \\
\hline Net non-debt creating capital inflows & 4.3 & 2.4 & -68.2 & -64.6 & -3.8 & -10.5 & 29.7 & 5.5 & 4.1 & 3.7 & 2.3 & 1.7 & 1.2 & $\ldots$ \\
\hline
\end{tabular}

$1 /$ Derived as $[r-g-r(1+g)+$ ea(1 $1+r)] /(1+g+r+g r)$ times previous period debt stock, with $r=$ nominal effective interest rate on external debt, $r=$ change in domestic GDP deflator in US dollar terms, $g=$ real GDP growth rate,

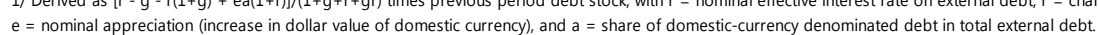

$\mathrm{e}=$ nominal appreciation (increase in dollar value of domestic currency), and $\mathrm{a}=$ share of domestic-currency denominated debt in total external debt.
$2 /$ The contribution from price and exchange rate changes is defined as $[-r(1+g)+$ ea( $(1+r) /(1+g+r+g r)$ times previous period debt stock $r$ increases with an appreciating domestic currency (e $>0$ ) and rising inflation (based on GDP defflator) 3 / For projection, line includes the impact of price and exchange rate changes.

4/ Defined as current account deficit, plus amortization on medium- and long-term debt, plus short-term debt at end of previous period.

5/ The key variables include real GDP growth; nominal interest rate; dollar deflator growth; and both non-interest current account and non-debt inflows in percent of GDP.

6/ Long-run, constant balance that stabilizes the debt ratio assuming that key variables (real GDP growth, nominal interest rate, dollar deflator growth, and non-debt inflows in percent of GDP) remain at their levels

of the last projection year.
$7 /$ External debt in Cyprus is made up to a large extent by non-resident deposits. In light of the more stable nature of these deposits together with the existence of liquidity provisions, risks stemming from external debt are smaller than what the headline debt number may suggest 
Table 6. Cyprus Core Financial Soundness Indicators for Deposit Takers 2007- 2011 1/

(Percent, otherwise indicated)

Financial Soundness Indicators 2008 Q4 2009 Q1 2009 Q2 2009 Q3 2009 Q4 2010 Q1 2010 Q2 2010 Q3 2010 Q4 2011 Q1 2011 Q2

Regulatory capital to risk-weighted assets

Regulatory tier 1 capital to risk-weighted assets

Core tier 1 capital to risk-weighted assets 2/

Non-performing loans net of provisions to capital

Non-performing loans to total gross loans

Non-performing loans to gross loans, alternative

definition 3/

Sectoral distribution of total loans:

\section{Residents}

Deposit-takers

Central Bank

Other financial corporations

General government

Nonfinancial corporations

Other domestic sectors

Nonresidents

Return on assets

Return on equity

Interest margin to gross income

Non-interest expenses to gross income

Liquid assets to total assets (liquid asset ratio)

Liquid assets to short-term liabilities

Net open position in foreign exchange to capital

\begin{tabular}{|c|c|c|c|c|c|c|c|c|c|c|}
\hline 10.6 & $\ldots$ & $\ldots$ & $\ldots$ & 11.8 & 11.5 & 11.6 & 11.7 & 12.2 & 12.9 & 12.9 \\
\hline 8.1 & $\ldots$ & $\ldots$ & $\ldots$ & 9.4 & 9.8 & 10.1 & 10.2 & 10.7 & 11.6 & 11.6 \\
\hline 7.3 & $\ldots$ & $\ldots$ & $\ldots$ & 7.3 & 7.7 & 7.5 & 7.7 & 8.1 & 9.0 & 8.6 \\
\hline 16.1 & 22.3 & 19.8 & 20.9 & 23.5 & 25.8 & 26.4 & 30.8 & 33.4 & 34.8 & $\ldots$ \\
\hline 4.6 & $\ldots$ & $\ldots$ & $\ldots$ & 5.9 & 6.3 & 6.6 & 7.2 & 7.3 & 7.6 & 8.1 \\
\hline$\ldots$ & $\ldots$ & $\ldots$ & $\ldots$ & 9.8 & 10.4 & 10.7 & 12.3 & 12.1 & 12.0 & 13.9 \\
\hline 39.5 & 36.7 & 37.0 & 37.2 & 40.0 & 38.8 & 39.2 & 38.6 & 38.9 & 39.9 & $\ldots$ \\
\hline 1.4 & 0.6 & 0.6 & 0.7 & 1.0 & 0.9 & 1.0 & 1.2 & 1.1 & 1.1 & $\ldots$ \\
\hline 1.3 & 0.8 & 1.6 & 1.1 & 3.0 & 1.5 & 3.2 & 1.1 & 2.1 & 1.0 & $\ldots$ \\
\hline 1.9 & 2.1 & 1.9 & 1.9 & 2.4 & 2.4 & 2.8 & 2.9 & 2.4 & 3.1 & $\ldots$ \\
\hline 1.0 & 0.9 & 0.9 & 0.9 & 0.9 & 0.9 & 0.8 & 0.9 & 0.9 & 0.9 & $\ldots$ \\
\hline 21.4 & 20.5 & 20.4 & 20.6 & 20.4 & 20.7 & 19.6 & 20.2 & 20.2 & 20.9 & $\ldots$ \\
\hline 12.4 & 11.9 & 11.6 & 12.0 & 12.3 & 12.4 & 11.7 & 12.3 & 12.3 & 12.9 & $\ldots$ \\
\hline 60.5 & 63.3 & 63.0 & 62.8 & 60.0 & 61.2 & 60.8 & 61.4 & 61.1 & 60.1 & $\ldots$ \\
\hline 1.0 & 0.2 & 0.4 & 0.7 & 0.8 & 0.2 & 0.3 & 0.5 & 0.6 & 0.2 & -0.5 \\
\hline 14.5 & 2.8 & 6.5 & 11.1 & 14.0 & 3.6 & 6.6 & 9.1 & 11.0 & 3.1 & $\ldots$ \\
\hline 67.9 & 65.2 & 66.8 & 65.9 & 66.7 & 72.2 & 74.5 & 75.9 & 75.6 & 73.1 & 78.0 \\
\hline 52.1 & 54.4 & 51.1 & 48.8 & 50.6 & 50.8 & 52.9 & 53.4 & 53.5 & 49.4 & $\ldots$ \\
\hline 36.5 & 41.1 & 46.4 & 43.6 & 40.1 & 39.5 & 43.1 & 37.1 & 32.4 & 27.0 & $\ldots$ \\
\hline 46.5 & 56.4 & 63.9 & 57.9 & 51.2 & 51.6 & 56.7 & 46.5 & 40.8 & 43.8 & $\ldots$ \\
\hline 0.8 & 1.2 & 0.8 & 0.9 & 1.0 & 1.5 & 1.0 & 1.0 & 1.0 & 0.9 & $\ldots$ \\
\hline
\end{tabular}

Source: IMF, Financial Soundness Indicators (FSI) . Data extracted from IMF Data Warehouse on 9/9/2011.

$1 /$ The data used for the first six financial soundness indicators is from the Banking Supervision Department of the Central Bank given its more timely nature.

However, the data provided had missing values for Q1 through Q3 2009.

2/ Banks for which CBC is the home supervisor

3/ NPLs of commercial banks on local operations only--including loans fully covered by tangible collateral. 
This page intentionally left blank

(CInternational Monetary Fund. Not for Redistribution 


\section{INTERNATIONAL MONETARY FUND}

\section{CYPRUS}

STAFF REPORT FOR THE 2011 ARTICLE IV

CONSULTATION-INFORMATIONAL ANNEX

November 3, 2011

Prepared By

European Department

(In Consultation with Other Departments)

\section{CONTENTS}

FUND RELATIONS $\underline{2}$ 


\section{ANNEX I: CYPRUS-FUND RELATIONS}

(As of September 30, 2011)

Membership Status: Joined December 21, 1961; Article VIII

\section{General Resources Account:}

$\begin{array}{lcc} & \text { SDR Million } & \text { Percent Quota } \\ \text { Quota } & 158.20 & 100.0 \\ \begin{array}{l}\text { Fund holdings } \\ \text { of currency }\end{array} & 99.72 & 63.03 \\ \begin{array}{l}\text { Reserve Tranche } \\ \text { Position }\end{array} & 58.52 & 36.99\end{array}$

\section{SDR Department:}

Percent

SDR Million

Allocation

Net cumulative

$\begin{array}{lll}\text { allocation } & 132.80 & 100.00 \\ \text { Holdings } & 139.46 & 105.01\end{array}$

\section{Outstanding Purchases and Loans: None}

Financial Arrangements: None

Projected Obligations to Fund (SDR million; based on existing use of resources and present holdings of SDRs):

\begin{tabular}{lccccc}
\hline & \multicolumn{5}{c}{ Forthcoming } \\
\cline { 2 - 6 } & 2010 & 2011 & 2012 & 2013 & 2014 \\
\hline $\begin{array}{l}\text { Principal } \\
\text { Charges }\end{array}$ & 0.00 & 0.00 & 0.00 & 0.00 & 0.00 \\
/Interest & & & & & \\
Total & 0.00 & 0.00 & 0.00 & 0.00 & 0.00 \\
\hline
\end{tabular}

Exchange Rate Arrangement: Cyprus adopted the euro on January 1, 2008. The currency floats freely and independently against other currencies. Cyprus has accepted the obligations of Article VIII, Sections 2, 3, and 4 and maintains an exchange system free of restrictions on the making of payments and transfers for current transactions.

Article IV Consultation: Cyprus is on a 12-month cycle. The previous Article IV Consultation mission took place during June 24 - July 5, 2010, and the staff report (CR/10/291) was discussed by the Executive Board on August 27, 2010.

FSAP Participation and ROSCs: An FSAP mission took place during September 23 - October 6, 2008. The FSAP Technical Notes were published in May 2009 (CR/09/167 and CR/09/171); the Financial System Stability Assessment (FSSA) was published in October 2009 (CR/09/308).

\section{Technical Assistance:}

Dept. Purpose

MAE Government debt management

FAD VAT training program

MAE Financial sector liberalization

MAE Reform of government securities

STA Special Data Dissemination Standard

STA Balance of Payments

STA Balance of Payments

STA Balance of Payments

STA Balance of Payments

FAD Public Investment and PPPs

AD Medium-term Budget Framework

AD Medium-term Budget Framework

STA Special Data Dissemination Standard

STA Balance of Payments
STA Special Data Dissemination Standard

\begin{tabular}{l}
\multicolumn{1}{c}{ Date } \\
February-March 1989 \\
June-October 1992 \\
November-December 1993 \\
April-May 1994 \\
August 1997 \\
March 1999 \\
May-July 2001 \\
November 2001-March 2002 \\
April-June 2002 \\
March-April 2006 \\
May 2006 \\
October 2007 \\
May 2007 \\
March 2009 \\
July 2011
\end{tabular}

Resident Representative: None. 


\section{ANNEX II: CYPRUS-STATISTICAL INFORMATION}

(As of October 31, 2011)

\section{A. Assessment of Data Adequacy for Surveillance}

General: Data provision is adequate for surveillance.

National Accounts: The transition to the new European System of Accounts 1995 (ESA 1995) has complicated the analysis of national accounts and fiscal data. The new national accounts do not provide information on the disposable income of households, thus hindering the calculation of the household saving ratio.

Financial sector data: The currency-linked and indexed bonds held by nonresidents are classified as domestic instead of foreign liabilities.

External debt: The authorities have decided to include non-resident deposits in resident banks in gross external debt.

Other: The Central Bank has started to compile data on property prices and household sector assets in 2009.

\section{B. Data Standards and Quality}

Cyprus subscribed to the IMF's Special Data Dissemination Standard (SDDS) on December 1, 2009 and has posted the metadata on the Dissemination Standards Bulletin Board (DSBB). Cyprus' economic database is comprehensive and of generally good quality. Data are provided to the Fund in a comprehensive manner (see attached table). The authorities regularly publish a wide range of economic and financial data, as well as a calendar of dates for the main statistical releases. Cyprus is also subject to the statistical requirements and timeliness and reporting standards of Eurostat and the European Central Bank (ECB), and has adopted the European System of Accounts 1995 (ESA95). No data ROSC is available. 


\section{Cyprus: Table of Common Indicators Required for Surveillance}

(As of October 28, 2011)

\begin{tabular}{|c|c|c|c|c|c|}
\hline & $\begin{array}{l}\text { Date of latest } \\
\text { observation }\end{array}$ & $\begin{array}{l}\text { Date } \\
\text { received }\end{array}$ & $\begin{array}{l}\text { Frequency } \\
\text { of Data }^{7}\end{array}$ & $\begin{array}{l}\text { Frequency of } \\
\text { Reporting }^{7}\end{array}$ & $\begin{array}{l}\text { Frequency of } \\
\text { Publication }^{7}\end{array}$ \\
\hline Exchange Rates & Current & Current & $\mathrm{D}$ & $\mathrm{D}$ & $\mathrm{D}$ \\
\hline $\begin{array}{l}\text { International Reserve Assets } \\
\text { and Reserve Liabilities of the } \\
\text { Monetary Authorities }{ }^{1}\end{array}$ & Sept. 2011 & Oct. 2011 & M & M & M \\
\hline Reserve/Base Money & Sept. 2011 & Oct. 2011 & M & M & M \\
\hline Broad Money & Sept. 2011 & Oct. 2011 & M & M & M \\
\hline Central Bank Balance Sheet & Sept. 2011 & Oct. 2011 & M & M & M \\
\hline $\begin{array}{l}\text { Consolidated Balance Sheet } \\
\text { of the Banking System }\end{array}$ & Sept. 2011 & Oct. 2011 & M & M & M \\
\hline Interest Rates $^{2}$ & Sept. 2011 & Oct. 2011 & M & M & M \\
\hline Consumer Price Index & Sept. 2011 & Oct. 2011 & M & M & M \\
\hline $\begin{array}{l}\text { Revenue, Expenditure, } \\
\text { Balance and Composition of } \\
\text { Financing }{ }^{3}-\text { General } \\
\text { Government }^{4}\end{array}$ & Q2 2011 & Oct. 2011 & $\mathrm{Q}$ & $\mathrm{Q}$ & $\mathrm{Q}$ \\
\hline $\begin{array}{l}\text { Revenue, Expenditure, } \\
\text { Balance and Composition of } \\
\text { Financing }{ }^{3}-\text { Central } \\
\text { Government }\end{array}$ & Aug. 2011 & Oct. 2011 & M & M & M \\
\hline $\begin{array}{l}\text { Stocks of Central Government } \\
\text { and Central Government- } \\
\text { Guaranteed Debt }\end{array}$ & Q2 2011 & Oct. 2011 & $\mathrm{Q}$ & $\mathrm{Q}$ & Q \\
\hline $\begin{array}{l}\text { External Current Account } \\
\text { Balance }\end{array}$ & Q1 2011 & Aug. 2011 & $\mathrm{Q}$ & $\mathrm{Q}$ & Q \\
\hline $\begin{array}{l}\text { Exports and Imports of Goods } \\
\text { and Services }\end{array}$ & Q1 2011 & Aug. 2011 & $\mathrm{Q}$ & Q & Q \\
\hline GDP/GNP & Q2 2011 & Oct. 2011 & Q & $\mathrm{Q}$ & Q \\
\hline Gross External Debt & Q1 2011 & Aug. 2011 & $\mathrm{Q}$ & $\mathrm{Q}$ & Q \\
\hline $\begin{array}{l}\text { International Investment } \\
\text { Position }^{6}\end{array}$ & Q1 2011 & Aug. 2011 & $\mathrm{Q}$ & $\mathrm{Q}$ & Q \\
\hline
\end{tabular}

1 Any reserve assets that are pledged of otherwise encumbered should be specified separately. Also, data should comprise short-term liabilities linked to a foreign currency but settled by other means as well as the notional values of financial derivatives to pay and to receive foreign currency, including those linked to a foreign currency but settled by other means.

2 Both market-based and officially-determined, including discount rates, money market rates, rates on treasury bills, notes and bonds.

3 Foreign, domestic bank, and domestic nonbank financing.

4 The general government consists of the central government (budgetary funds, extra budgetary funds, and social security funds) and state and local governments.

5 Including currency and maturity composition.

6 Includes external gross financial asset and liability positions vis-à-vis nonresidents.

7 Daily (D); weekly (W); monthly (M); quarterly (Q); annually (A); irregular (I); and not available (NA). 
Public Information Notice (PIN) No. 11/xx

FOR IMMEDIATE RELEASE

November XX, 2011
International Monetary Fund

$70019^{\text {th }}$ Street, NW

Washington, D. C. 20431 USA

\section{IMF Executive Board Concludes 2011 Article IV Consultation with Cyprus}

On November 18, 2011, the Executive Board of the International Monetary Fund (IMF) concluded the Article IV consultation with Cyprus. ${ }^{1}$

\section{Background}

The Cypriot economy faces strong headwinds and downside risks due to financial turbulence in the euro area, the large exposure of Cypriot banks to Greece, and the need for substantial fiscal consolidation to stabilize public finances. Reflecting these developments, the government has lost access to international capital markets and confronts the challenge of accessing financing to meet its fiscal needs in 2012 and beyond.

Following a weak recovery in 2010, staff expects no economic growth this year and a modest contraction in 2012. Factors that will weigh upon growth include tight credit and a climate of uncertainty, continued downsizing of the construction sector after past excesses, slowing external demand, and planned fiscal consolidation. Downside risks are dominant, in light of the potential for external conditions to worsen and for adverse feedback loops between fiscal imbalances and bank balance sheet vulnerabilities.

\footnotetext{
${ }^{1}$ Under Article IV of the IMF's Articles of Agreement, the IMF holds bilateral discussions with members, usually every year. A staff team visits the country, collects economic and financial information, and discusses with officials the country's economic developments and policies. On return to headquarters, the staff prepares a report, which forms the basis for discussion by the Executive Board. At the conclusion of the discussion, the Managing Director, as Chairman of the Board, summarizes the views of Executive Directors, and this summary is transmitted to the country's authorities.
}

Washington, D.C. 20431 • Telephone 202-623-7100 • Fax 202-623-6772 • www.imf.org 
Fiscal balances have deteriorated sharply over the past three years, reflecting in large part underlying structural factors. Adjustment measures planned for 2011 fell short of target, and staff expect the deficit to widen to some 7 percent of GDP in 2011. The authorities have renewed their commitment to restore sound public finances. They have passed a first package of adjustment measures and are seeking passage of a second and larger set of measures that would yield fiscal savings of some 4 percent of GDP in 2012, if fully implemented. Additional measures will be required to reduce the deficit further and achieve the government's target of a balanced budget by 2014. Over the longer-term, the public pension system will generate another source of fiscal pressures, as population aging and rising dependency ratios feed through to large increases in pension outlays.

The large banking sector, with assets totaling over 8 times GDP by the broadest measure, and with significant exposure to Greece, is a significant vulnerability. Banks face significant capital needs to reflect mark to market valuations on their sovereign bond holdings and to achieve a 9 percent core tier one capital ratio, as mandated by the European Banking Authority.

Non-performing loans are increasing, and further loan deterioration could add to recapitalization needs. Meanwhile, the system is also vulnerable to an outflow of deposits in the event of adverse circumstances. Cypriot banks receive significant liquidity support from the ECB.

\section{Executive Board Assessment}

The Executive Directors noted that Cyprus faces daunting economic challenges in the face of faltering external demand, growing exposure to the turmoil in the euro area, particularly in Greece, and worsening domestic financial conditions. Directors thus urged the authorities to act forcefully to restore sound public finances and safeguard the stability of the banking system. Steadfast implementation of fiscal and structural reforms on several fronts would also be critical for a return to durable growth over the medium term.

Directors agreed that an ambitious and credible fiscal adjustment is essential to regain access to the international capital markets and put the public debt ratio on a downward path. They supported the authorities' plans to achieve fiscal balance over the next three years as an appropriate strategy for undertaking the necessary fiscal correction without unduly damaging growth prospects. Directors considered that front-loading the adjustment with measures to reverse recent increases in public sector wages and poorly targeted transfers would provide a credible signal of the authorities' commitment to medium-term consolidation and bolster investor confidence. Reforms of the cost-of-living allowance system would also be important for achieving the fiscal targets and improving real wage flexibility and competitiveness.

Directors underscored the importance of other fiscal reforms to underpin the consolidation efforts. Priorities should include the introduction of a medium-term budget framework and the adoption of fiscal rules consistent with EU directives. Directors also highlighted the 
need for reforming the national pension and healthcare systems, which threaten to put unsustainable pressures on the budget as the population ages.

Directors expressed concern about the vulnerabilities arising from Cyprus's large banking sector and the possibility of adverse feedback loops with the public finances and the real economy in the context of weakening balance sheets. They stressed the importance of building prudent capital buffers and of ensuring adequate liquidity in the financial system. These actions should be supported by contingency planning and the immediate passage of legislation to provide the authorities with full powers to recapitalize or resolve banks, if necessary. Cooperative credit institutions should also be watched closely and brought under the same regulatory and supervisory frameworks as banks.

It is expected that the next Article IV consultation with Cyprus will be held on the standard 12-month cycle.

Public Information Notices (PINs) form part of the IMF's efforts to promote transparency of the IMF's views and analysis of economic developments and policies. With the consent of the country (or countries) concerned, PINs are issued after Executive Board discussions of Article IV consultations with member countries, of its surveillance of developments at the regional level, of post-program monitoring, and of ex post assessments of member countries with longer-term program engagements. PINs are also issued after Executive Board discussions of general policy matters, unless otherwise decided by the Executive Board in a particular case. 
Cyprus: Selected Economic Indicators, 2006-11

(Annual percentage change, unless otherwise indicated)

\begin{tabular}{|c|c|c|c|c|c|c|}
\hline & 2006 & 2007 & 2008 & 2009 & 2010 & $20111 /$ \\
\hline \multicolumn{7}{|l|}{ Real economy } \\
\hline Gross domestic product & 4.1 & 5.1 & 3.6 & -1.9 & 1.1 & 0.0 \\
\hline Domestic demand (contribution to annual growth) & 6.2 & 9.1 & 7.5 & -6.3 & 0.3 & -0.5 \\
\hline Harmonized index of consumer prices (period average) & 2.2 & 2.2 & 4.4 & 0.2 & 2.6 & 4.0 \\
\hline Unemployment rate (percent) & 4.6 & 4.0 & 3.6 & 5.4 & 6.4 & 7.6 \\
\hline \multicolumn{7}{|l|}{ Public finances (general government, percent of GDP) } \\
\hline Overall balance & -1.2 & 3.4 & 0.9 & -5.9 & -5.3 & -7.0 \\
\hline Primary balance & 2.1 & 6.4 & 3.7 & -3.4 & -3.1 & -4.4 \\
\hline Gross public debt & 64.1 & 58.0 & 48.2 & 57.8 & 60.7 & 64.0 \\
\hline \multicolumn{7}{|l|}{ Interest rates (percent) } \\
\hline Deposit rates 2/ & $\ldots$ & 4.4 & 4.9 & 3.7 & 3.6 & $\ldots$ \\
\hline Lending rates $3 /$ & $\ldots$ & 6.3 & 6.7 & 6.9 & 5.8 & $\ldots$ \\
\hline \multicolumn{7}{|l|}{ Balance of payments (percent of GDP) } \\
\hline Trade balance (goods and services) & -4.0 & -6.5 & -11.0 & -5.1 & -5.1 & -4.4 \\
\hline Current account balance & -6.9 & -11.7 & -16.8 & -7.8 & -7.7 & -7.2 \\
\hline \multicolumn{7}{|l|}{ Fund Position (September 30, 2011) } \\
\hline Holdings of Currency (percent of quota) & & & & & & 63.0 \\
\hline Holdings of SDR's (percent of allocation) & & & & & & 105.0 \\
\hline Quota (millions of SDR) & & & & & & 158.2 \\
\hline \multicolumn{7}{|l|}{ Exchange rates } \\
\hline Exchange rate regime & \multicolumn{6}{|c|}{ Euro Area Member } \\
\hline Present rate (November 2, 2011) & US\$ 1 & 38 per $\epsilon$ & uro & & & \\
\hline Nominal effective exchange rate $(2005=100)$ & 100.6 & 100.3 & 102.5 & 104.3 & 101.9 & $\ldots$ \\
\hline Real effective exchange rate (HIPC, 2005 $=100)$ & 100.4 & 99.9 & 102.6 & 103.5 & 101.1 & $\ldots$ \\
\hline
\end{tabular}

Sources: Eurostat; Central Bank of Cyprus; and IMF staff estimates.

1/ Data for 2011 are projections.

2/ Due to a change in methodology, comparable interest rate data are available since November 2007. For 2007 data refers to the average of MFI interest rates on new deposits for households and non-financial corporations up to 1 year for November and December. Starting from 2008, the same average covers the whole year. 3 / Due to a change in methodology, comparable interest rate data are available since November 2007. For 2007 data refers to the average of MFI interest rates on new loans for households and non-financial corporations up to 1 year for November and December. Starting from 2008, the same average covers the whole year. 


\section{Statement by Menno Snel, Executive Director for Cyprus, and Ester Barendregt, Senior Advisor to the Executive Director for Cyprus}

November 18, 2011

\section{Introduction}

The authorities thank the staff for helpful discussions in Cyprus and for their thorough analysis, which they broadly share. In view of the adverse external developments, they are vigilant and have agreed to remain in close contact with the staff so as to keep them abreast of the impact of these developments in Cyprus and to discuss policy responses, including in the context of technical assistance.

Cyprus has a history of stable economic growth and responsible fiscal policies. A businessfriendly environment and a well-educated population have contributed to its economic success over the years. Following a recession in 2009, positive real growth was registered in 2010. For 2011, the government had projected 1.5 percent growth and the outcomes in the first two quarters of this year were in line with this projection. However, a deteriorating external environment and the tragic explosion on $11^{\text {th }}$ July that destroyed the Vasiliko power plant have had a negative effect on the outlook. Moreover, the worsening situation in Greece has negatively affected economic confidence in Cyprus, where banks have high exposure to Greece. Rating agencies have highlighted the interrelatedness of the large Cypriot banking sector with the Greek economy together with deteriorated fiscal performance as the main factors for their recent downgrades of the Cypriot sovereign. Since June, Cyprus has effectively lost access to international sovereign debt markets. The authorities are fully aware of the seriousness of this situation and have focused their efforts on strongly improving the fiscal position in an effort to attract external financing and to ensure financial sector stability. The government which emerged following the reshuffle of August is committed to achieving these objectives.

\section{Economic and fiscal outlook}

The economic impact of the Vasiliko-explosion appears less pronounced than was feared at first. Especially the services sector is performing better than foreseen. The government now expects growth for 2011 to turn out at around 0.5 percent, at the higher end of the postVasiliko projections. For 2012, the government's preliminary projections point to a possible

0.2 percent growth, mainly on account of promising prospects for tourism and in general for the services sector, as evidenced by forward-looking indicators. They acknowledge the highly uncertain global environment and particularly the risks related to the European debt crisis. For the medium to longer term, potential gas reserves offshore Cyprus constitute an upside potential for economic growth prospects. 
Fiscal outcomes in the first half of this year were significantly worse than budgeted. This is explained by some one-off factors, but also by factors of a more structural nature such as higher outlays for unemployment benefits and, admittedly, by delays in the implementation of corrective measures. However, fiscal performance has somewhat stabilized in the last months despite the deteriorated economic environment. Performance has been helped by the less pronounced fall in growth, better than forecast corporate tax revenues and the effect of the first package of corrective measures adopted on August 26th. Fiscal outcomes for the months of August and September were close to the original forecast (the deficit for 2011 was originally forecast at 4 percent). On this basis, the government's latest projection is that the fiscal deficit for 2011 will be substantially higher than budgeted, but will remain somewhat below 6 percent of GDP.

\section{Fiscal consolidation}

The government is firmly committed to fiscal consolidation and to addressing market concerns. In the House of Representatives, where the government does not have a majority, broad consensus exists on the need for large fiscal consolidation. However, there are differences on some aspects of the fiscal consolidation package.

The government aims to reach a deficit below 3 percent for 2012 and a balanced budget by 2014 and has already proposed two sets of measures that should achieve the bulk of this effort. Together, these packages are estimated to reduce the deficit by approximately 4 percent of GDP. The largest part of the adjustment will be on the expenditure side. The measures will primarily address wage dynamics and the public wage bill through a frontloaded adjustment, and are mostly of a structural and permanent nature. Targeting of social measures is another important element, which should preserve social fairness. The authorities welcome staff's encouragement that this is an ambitious, but appropriate pace of consolidation. A first package of measures was approved by Parliament in August, and a second package is currently in Parliament as part of the proceedings for the 2012 budget.

As for the specific measures taken, the following are especially worth noting: The first package introduced for the first time in Cyprus a contribution by employees to the public pension scheme, and the abolition of the separate occupational public pension for new entrants. Revenue enhancing measures were also part of this package, including an increase of the withholding tax on interest, the introduction of a levy on all registered companies, and an increase in the highest marginal income tax rate. The second package, which is currently in Parliament, includes further measures to contain the public sector wage bill such as the abolition of all vacant posts, a reduction of personnel in the broader public sector (one recruitment for every four retirements), as well as a 10 percent reduction of salary scales for newly recruited personnel, the impact of which will grow over time. The importance of the agreement on the freeze in the cost-of-living adjustment (COLA) during the first half of 2012 should not be underestimated, as the COLA has been a deeply embedded element of the labor 
market framework in Cyprus. Targeting of social benefits based on income and other economic criteria and, on the revenue side, an increase in the standard VAT rate from 15 percent to 17 percent are the other main elements of this second package. The proposed VAT rate increase is the most debated element in parliament.

Importantly, in addition to these elements discussions with the social partners have started on reform of the COLA. This discussion is expected to be finalized by the end of this year. One of the options being considered is to keep the COLA payments constant above a certain threshold as a permanent arrangement.

The Minister of Finance has publicly announced that the government will look into passing new measures, beyond those passed in August and those included in the 2012 budget. In this context, the government intends to start a dialogue with social partners on a wage freeze. Moreover, the authorities are committed to taking further measures in order to reach the fiscal consolidation targets set for the 2013 and 2014 budgets in the context of the Three Year Budgetary Plan, which will be revised early next year. Windfall revenues will be used for deficit reduction.

\section{Financing}

The government's policies set out in this Buff are aimed at regaining access to international capital markets within a reasonable timeframe. For the near future, however, the lack of access to international sovereign bond markets poses important challenges for securing adequate financing beyond 2011. The government has secured a EUR 2.5 billion loan from Russia, which will be disbursed in three tranches between the end of this year and April 2012. The remaining needs for financing the deficit and rolling over maturing debt until the end of 2012 are estimated at EUR 700 million (taking into account fiscal consolidation plans). This is expected to be covered by short-term debt and/or long-term domestic debt.

The authorities follow the developments with respect to the European debt crisis closely, and consider their options in case these would have prolonged negative effects on the country's financing abilities. It is worth noting that the authorities have advanced plans for improving their debt management framework. New legislation dealing with all aspects of debt management is being prepared in collaboration with the World Bank.

\section{Pensions, Public Financial Management}

The government is preparing a draft law that will introduce a medium-term budgetary framework and ensure compliance with the EU fiscal framework Directives. The IMF staff has been invited to review the draft and to advise on practical implementation issues. The authorities are considering to request Fund technical assistance in the fields of natural resources contracts taxation; (for the medium term) natural resources revenue management; and revenue administration. 
The government furthermore is currently reviewing the new actuarial study of the national pension scheme and its implications for fiscal sustainability. In this context the study of the IMF on the pension system in Cyprus will provide a helpful input.

\section{Financial sector}

The Cypriot financial sector is large in terms of GDP, and has been an important pillar of the economic model. Cypriot banks conduct mainstream banking (mostly deposit taking and loan granting). They have low dependency on wholesale funding. The regulatory framework is conservative, as is illustrated by strict liquidity requirements and the relatively high minimum capital ratios (minimum core tier 1 capital of 8 percent of risk-weighted assets) . The two largest banks already comply with the Basel III minimum capital ratios. Moreover, the supervisor has required Cypriot banks to build up available adequate core tier 1 capital of at least 8 percent plus an additional amount reflecting the ratio of their total assets to the Cypriot GDP by the end of 2014. However, the interconnectedness of the banking sector with the Greek economy and the recent downgrades by rating agencies have made the sector vulnerable. The private sector involvement in the Greek program that was agreed on the 26 October Euro Area Summit, implies high costs for Cypriot banks. Additional needs come from the new EBA requirements for banks to mark sovereign exposures to market and to increase their core tier 1 capital ratio to 9 percent by June 2012. The figures reported by the EBA already include mark-to-market valuation for Greek government bonds.

In response to these developments, the authorities continue to monitor the situation very closely and take preventive measures. They monitor liquidity and undertake rigorous stress testing (including scenarios for significant increases in NPLs and bad debt provisions) on a regular basis, are developing contingency plans, and are strengthening the legal framework, including with the help of Fund TA. The authorities expect to publish in the second half of this month the final figures for the expected capital buffer for individual banks according to the new EBA requirements. They expect that the shortfalls will be lower than the preliminary figure announced by the EBA, the difference being explained inter alia by the specific characteristics of each bond (where the EBA necessarily had to make certain common assumptions). At this stage, the authorities expect the banks to be in a position to cover their capital needs according to the new EBA requirements. The supervisor will work with the banks on plans to meet the requirements. The authorities note that Cyprus banks have substantial contingent convertible capital instruments, which are compliant with Basel III and with the relevant CEBS guidelines. Therefore, they expect that these instruments will be eligible to cover part of the sovereign buffer required by the EBA.

The authorities have undertaken to strengthen the legal framework by the following three elements: First, the draft Law on Establishment and Operation of the Independent Financial Stability Fund is being discussed in parliament. Once approved, this law will enable the establishment and running of a Financial Stability Fund. This Fund will gradually be built up 
by bank and cooperative credit institutions' contributions and, when required, will finance the implementation of the appropriate bank resolution tools by the competent authority. A second draft law, the Financial Crisis Management Law, is also in parliament. It aims to provide the Council of Ministers, upon a recommendation by the Central Bank of Cyprus, with the powers needed to effectively manage a financial crisis and maintain financial stability as well as public confidence in Cyprus's financial system. Thirdly, the current bank resolution regime is being strengthened through amendments in the Banking Law that will reinforce the powers of the Central Bank of Cyprus to take specific resolution measures visà-vis credit institutions. These draft law amendments will be submitted to parliament for approval by the end of this month.

Finally, the authorities thank the staff for very helpful technical assistance and advice in these areas. 